Article

\title{
Jurassic Non-Carbonate Microbialites from the Betic-Rifian Cordillera (Tethys Western End): Textures, Mineralogy, and Environmental Reconstruction
}

\author{
Matías Reolid *(D) and Isabel Abad $(\mathbb{D}$ \\ Departamento de Geología and CEACT, Universidad de Jaén, Campus Las Lagunillas s/n, 23071 Jaén, Spain; \\ miabad@ujaen.es \\ * Correspondence: mreolid@ujaen.es; Tel.: +34-953213316
}

Received: 12 December 2018; Accepted: 25 January 2019; Published: 30 January 2019

check for updates

\begin{abstract}
The term microbialite is commonly applied for describing carbonate organo-sedimentary deposits that have accreted as a result of the activity of benthic microbial communities (BMC). However, non-carbonate microbialites are progressively well-known and show a great diversity of organisms, processes, and mineralogical compositions. This article reviews three types of Jurassic microbialites from four different environmental contexts from the Betic-Rifian Cordillera (South Spain and North Morocco): marine hardgrounds, submarine caves, hydrothermal vents, and submarine volcanic deposits. The Middle-Late Jurassic transition in the External Subbetic (Betic Cordillera) and the Jbel Moussa Group (Rifian Calcareous Chain) was characterized by the fragmentation of the carbonate epicontinental platforms that favored these different settings: (A) Many stratigraphic breaks are recorded as hardgrounds with surficial hydrogenetic Fe crusts and macro-oncoids related to chemo-organotrophic behavior of BMC that served as a specific trap for Fe and Mn enrichment; (B) Cryptic hydrogenetic Fe-Mn crusts (or endostromatolites) grew in the walls of submarine cavities and fractures mainly constituted by Frutexites (chemosynthetic and cryptobiontic microorganism) locally associated to serpulids; (C) Hydrothermal Mn crusts are mainly constituted by different types of filaments and bacillus-shaped bacteria, whose mineralogy and geochemistry point to a submarine hydrothermal origin; (D) Finally, glauconite laminated crusts, constituted by branched cylindrical filaments, have grown in cryptic spaces among the pillow-lava bodies, probably related to the metabolism of chemo-organotrophic microbes under oxic conditions at temperatures between 30 and $90^{\circ} \mathrm{C}$. In most of the cases described in this work, microbial organisms forming microbialites were extremophiles.
\end{abstract}

Keywords: fossil microbes; Fe crusts; Mn crusts; glauconitic crusts; Subbetic; Rif

\section{Introduction}

Microbialites were defined by Burne and Moore [1] as organo-sedimentary deposits that have developed as a result of a benthic microbial community (BMC) trapping and binding detrital sediment or forming the locus of mineral precipitation. This term has been mainly used in the study of microbial carbonates [2-5].

However, other types of non-carbonate rocks are also organo-sedimentary deposits, resulting from different processes of BMC. There are examples related to iron oxides and oxyhydroxides [6,7], manganese oxides [8-10], phosphates [11-13], sulfates [14-17], and silicates [18]. Some of these examples are related to extremophile microbes $[16,19,20]$, and they hold great interest for the study of the origin of life [21-23] and for astrobiology [24-26]. 
Most commonly, microorganisms generate biofilms, structures of extracellular polymeric substances (EPS) formed by multiple species of bacteria, archaea, fungi, cyanobacteria, algae, and other microbial eukaryotes, each with a specific metabolic function. The EPS typically consist of polysaccharide, secondarily proteins, and nucleic acids. Biofilms allow BMC to attach to surfaces, afford protection from other microbial predators, and control the environmental conditions at microhabitat scale. The architecture of the biofilm and the thickness depend on many variables, such as nutrients, light availability, $\mathrm{pH}$, and redox gradients [27,28]. The EPS of biofilms increase the chemical gradients across it.

Evidence suggests that BMC are involved in the precipitation of specific metals, such as Fe and $\mathrm{Mn}$, and clayey materials in microbial mats [29-32]. A relevant mechanism in the microbe-mineral interactions is the biomineralization, i.e., microbially-mediated synthesis of minerals. Schultze-Lam et al. [33-35] have shown that exopolymeric substances exuded by microbial cells often provide nucleation sites and possibly a favorable chemical microenvironment for biomineralization.

According to Cuadros [36], substances secreted by BMC as by-products, gases from respiration, mineral species dissolved from the substrate surfaces or actively introduced from the surrounding environment, are all more concentrated within the biofilm. Specific Fe and Mn enrichment by extracellular traps in the microbial wall highlights the importance of microbial communities as a catalyzer in the mineral precipitation [37-40].

This article reviews three kinds of Jurassic microbial deposits from four different environmental contexts from the Betic-Rifian Cordillera (South Spain and North Morocco): marine hardgrounds, submarine caves, hydrothermal vents, and submarine volcanic deposits. Special attention is given to the geochemical aspects of the microbialites, for which analyses from new samples have been obtained. An updated review of the literature published about this topic has also been carried out.

\subsection{Fe-Mn Crusts}

Iron and manganese crusts from marine deposits are differentiated into three genetic types: diagenetic, hydrogenetic, and hydrothermal deposits [41-45]. Diagenetic deposits are developed from oxic-diagenesis within the underlying sediments, leading to an upward supply of $\mathrm{Mn}$ and $\mathrm{Fe}$ from the sediment column. Hydrogenetic deposits form directly from seawater under oxidizing conditions $[13,43,46-48]$. Finally, the hydrothermal Fe-Mn crusts precipitate from hydrothermal solutions that are vented in areas with relatively high heat flow associated with submarine volcanism, such as back-arc basins, mid-ocean ridges, and hot spot volcanoes $[23,43,49,50]$. The presence and the mediation of microbial biocoenoses in the growth of Fe and Mn crusts is usual in both hydrogenetic and hydrothermal examples [13,39,47,51,52]. Tashiro and Tazaki [53] determined that the EPS surrounding microbial cells could act as a template in the precipitation of iron hydroxides.

The geochemical and mineralogical composition of Fe and Mn laminated deposits from the Jurassic of the Betic-Rifian Cordillera was examined, as well as the record of microbial structures composing these deposits that allow them to be interpreted as microbialites.

\subsection{Clay Microbialites}

Microorganisms may also induce the precipitation of clay minerals from solutions (including colloidal components) and through the weathering of silicate minerals [36]. Clay minerals formed as a result of microbial activity are typically of variable composition and low crystal order [54]. For example, experiments of Fiore et al. [55] suggested that crystallization of kaolinite can be induced by the metabolism of bacteria in aluminosilicate gel.

A special relationship is found between Fe and microbes. Konhauser et al. [56] found that the BMC from the Rio Solimões, Brazilian Amazon Basin, accumulate Fe on the cellular membrane, followed by trapping of $\mathrm{Al}$ and $\mathrm{Si}$, resulting in very fine particles with clay mineral morphology and chamosite-like composition. Different studies and experiments point to a central role of Fe in the nucleation of clays with Si-Fe-Al composition on bacterial cells and EPS [29,56-58]. At near-neutral $\mathrm{pH}$, the bacterial 
cell walls and the EPS have a negative charge in their surface produced by carboxylic, hydroxyl, and phosphoryl groups, so they can attract and retain cation species, such as $\mathrm{Fe}^{3+}$. The presence of amino groups charged positively allow attachment of silicate anions [54,58]. Ueshima and Tazaki [59] propose that the formation of nontronite (a Fe-rich dioctahedral smectite commonly related to hydrothermal vents) is catalyzed by EPS from natural ferrosiliceous groundwater. Perri et al. [31] have recorded precipitates of amorphous nanoparticles that replace the ultrastructure of EPS from modern peritidal microbial mats from Qatar. These nanoparticles act as substrates for nucleation of palygorskite fibers surrounding bacterial bodies.

Sánchez-Navas et al. [60] recorded Si-Fe-Al smectite and gels of variable composition in phosphate stromatolites from Jurassic marine deposits of the Betic Cordillera. These authors proposed that Si-Fe-Al gels precipitated within the bacterial biofilms and suggested that this type of process could be a common precursor of glauconite (the generation of Fe-rich smectite is the first step in the formation of glauconite).

Clay microbialites are also the subject of this work. The analysis of the morphology and microstructure of the green laminated crusts composed by greenish phyllosilicates related to cryptic spaces among Jurassic pillow-lava bodies from South-Iberian Paleomargin provide the basis for the discussion of a possible role of microbes on the origin and growth of the crusts.

\section{Geological Setting and Jurassic Evolution}

The western Mediterranean Sea is limited by three alpine systems: the Apennines, the Betic Cordillera, and the Maghrebian Cordillera (Rif, Tell, and Sicily) (Figure 1). They are linked by two major tectonic structures, the Gibraltar Arc in the West and the Calabria-Peloritani Arc in the East, which illustrate the connection between different cordilleras and reveal the gradual change of vergence from one chain to another [61]. The outcrops studied correspond to different branches of the Gibraltar Arc, called the Betic-Rifian Cordillera (Figure 1).

In the Betic Cordillera, the analyzed outcrops correspond to the Subbetic (Betic External Zones). The Subbetic is the more distal area with respect to the Iberian Plate, and it is composed by four parts, which according to Vera [62] are from North (more proximal) to South (more distal): Intermediate Units, External Subbetic, Median Subbetic, and Internal Subbetic.

The studied examples from the Rifian Cordillera are located precisely in the Gibraltar Arc and crops out in the northernmost end of the Rifian Calcareous Chain (Figure 1), an area corresponding to the Jbel Moussa Group [63]. The Jbel Moussa Group represents a Jurassic pelagic swell, involving the external zones of the Gibraltar Arc (i.e., the Tariquid Ridge of Durand-Delga [64]). In turn, the Jbel Moussa Group is constituted by $4 \mathrm{~km}$-scale tectonic units represented by juxtaposed tilted blocks (Jbel Moussa, Jbel Juimâa, Ras Leona, and Leila) of a Jurassic continental passive paleomargin. El Kadiri et al. [65] and El Hatimi [66] show that the Jbel Moussa Group is equivalent to the Internal Subbetic from the stratigraphic point of view.

The Jurassic of the External Zones of the Betic Cordillera (Prebetic and Subbetic domains) and the Rifian Cordillera is constituted by sedimentary marine rocks deposited in the South-Iberian Paleomargin and the North Gondwana Paleomargin. These deposits have been interpreted from the perspective of basin analysis as the record of a rifting phase that controlled the formation of continental margins, where extensive epeiric carbonate platforms were developed during the Jurassic [52,62,67].

The progress of this rifting phase meant, in its early stages, the fracturing and dismemberment of the epeiric carbonate platform during the Early Jurassic. In the early stages of rift evolution, the tectonic phase of the Early Pliensbachian had a very significant impact [62]. As a consequence, the Prebetic and the Subbetic, the two great domains of the External Zones of the Betic Cordillera, were differentiated. Some areas of the Subbetic were dominated by pelagic sedimentation and the extensional process of crustal thinning favored the submarine volcanism. Jurassic pillow-lavas (from Pliensbachian to Oxfordian), intercalated between pelagic sediments, have been described in the Median Subbetic $[68,69]$. This fragmentation has been also described in the North Gondwana 
Paleomargin [70-73]. Finally, during the Early-Middle Jurassic transition, large-scale shallowing sequences finished again with shallow platform limestones.

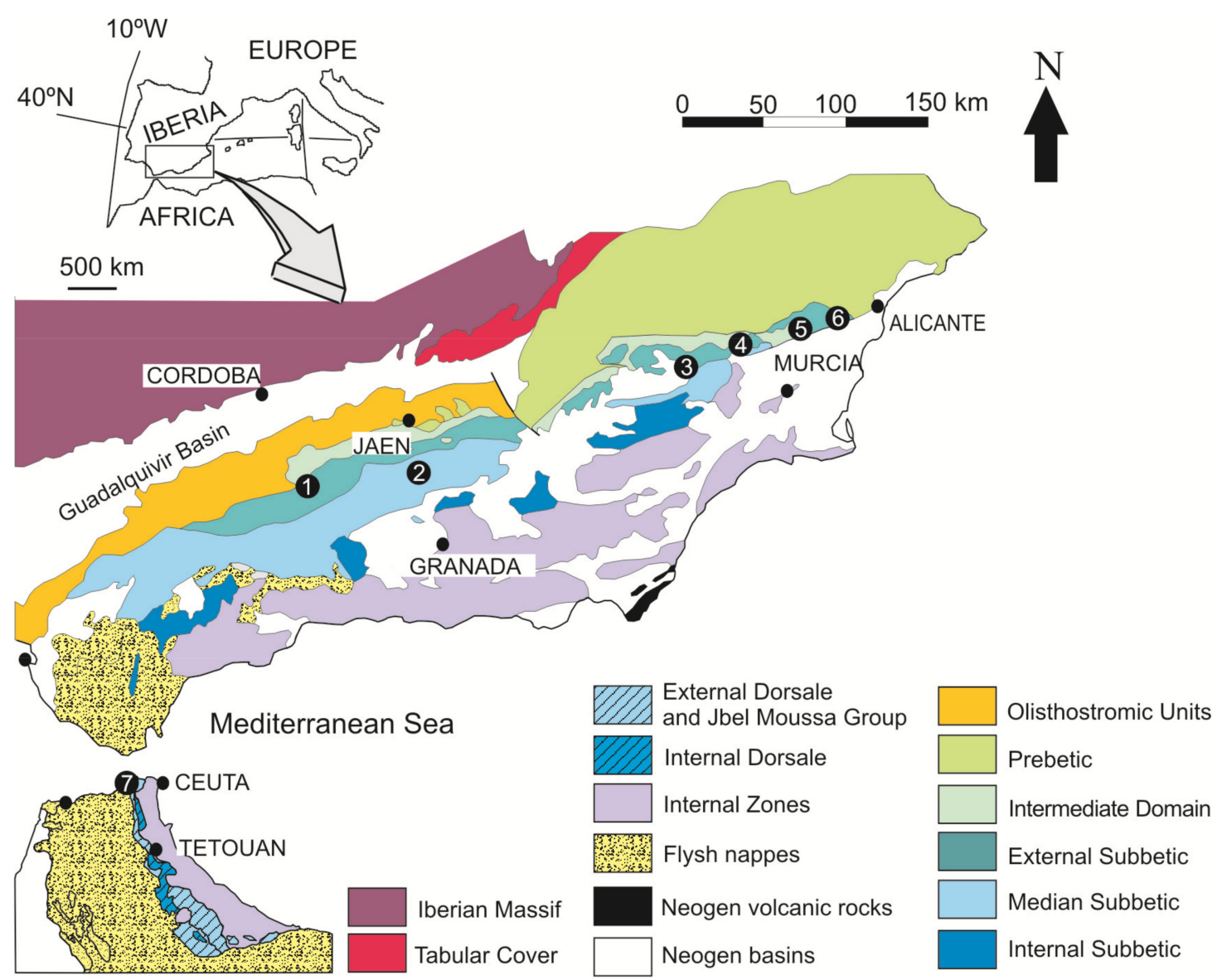

Figure 1. Geological setting of the studied outcrops in the Betic-Rifian Cordillera. (1) Cabra outcrop, (2) Carretero outcrop, (3) Quípar outcrop, (4) Lúgar outcrops, (5) Caprés outcrop, (6) Rambla Honda outcrop, (7) Ras Leona.

The expansive episode of the rifting began when the first oceanic crust was formed between the Iberian Plate and the Meso-Mediterranean terrain. This expansive episode (Figure 2) started towards the boundary between Bathonian-Callovian [62] and finished during the Late Berriasian. A paleogeographic reconstruction for Bathonian and Middle Oxfordian is showed in the Figure 2. During this episode, the Western Tethys was characterized by discontinuous sedimentation with complex stratigraphic breaks that separated Middle and Late Jurassic sedimentation. Such unconformities are represented in numerous domains presenting iron and manganese deposits, for instance, the Maghreb $[47,74,75]$, the Iberian Range [76-80], Schaignay [81], the Côte D'Or [82], the southeastern Paris Basin [83,84], the Swiss Juras [85,86], and Swabia [87]. In the case of the External Zones of the Betic Cordillera, representing the South-Iberian Paleomargin, important stratigraphic gaps and unconformities have been recorded for the Bathonian-Oxfordian [52,62,67,88-97]. After this tectonic event, there was a clear differentiation between subsident troughs and less subsident swells limited by faults (horst-graben systems or tilted blocks related to listric faults $[51,75,95,98])$. 

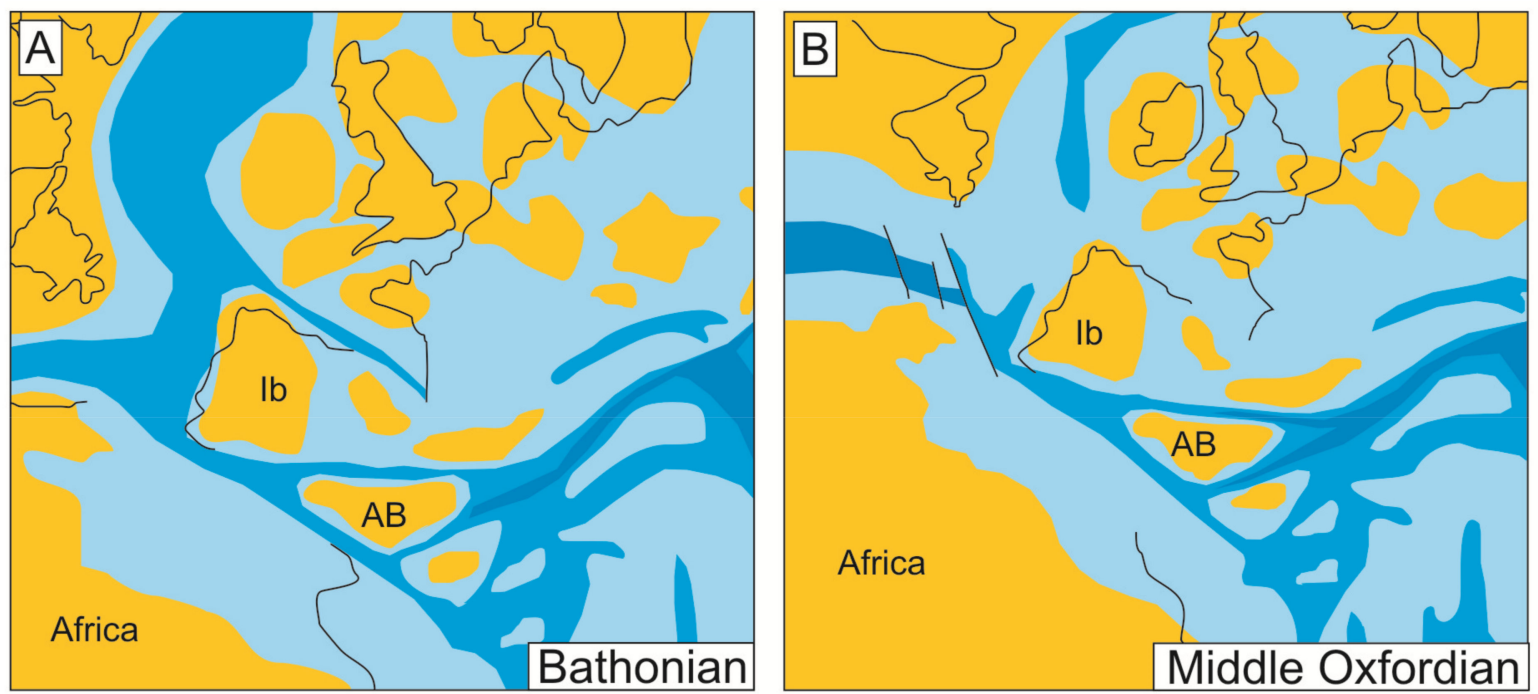

Emerged continental areas

Epicontinental seas

Deep marine areas with thin continental crust

Deep marine areas with oceanic crust

Figure 2. Paleogeographic reconstruction of the western part of the Tethys during the Bathonian (A) and the Middle Oxfordian (B). Ib: Iberian Massif and AB: Alboran Block.

\section{Studied Outcrops}

\subsection{External Subbetic}

The External Subbetic is a domain of the Subbetic, located between the Intermediate Units to the North and the Median Subbetic to the South [62]. In the External Subbetic, outcrops selected are located in the provinces of Córdoba, Murcia, and Alicante (SE Spain). The outcrops correspond to four different tectonic units of the Central and Eastern parts of the Subbetic.

During the Middle Jurassic, sedimentation in the External Subbetic was varied, represented today by oolitic limestones (Camarena Formation) in the Central External Subbetic, and the condensed limestones (Upper Ammonitico Rosso Fm) in the Eastern External Subbetic (Figure 3). The Upper Jurassic is represented only by the Upper Ammonitico Rosso Fm in all tectonic units. An unconformity was developed between Middle and Upper Jurassic deposits related to the expansive episode of the rifting (Figure 3). The age of the unconformity varies, with a maximum from Late Bathonian to Late Oxfordian [99-101].

In the Central External Subbetic, the top of the Camarena Fm is characterized by the presence of iron laminated crusts and common neptunian-dykes and sills (Figure 4A,B), interpreted as having a paleokarstic origin [102-104]. The selected outcrop is located in the Barranco de Navahermosa ( $37^{\circ} 30^{\prime} 7^{\prime \prime} \mathrm{N}, 4^{\circ} 18^{\prime} 32^{\prime \prime} \mathrm{W}$; Córdoba province).

In the Eastern External Subbetic, a lower and an upper member have been differentiated in the Upper Ammonitico Rosso Fm [100,101]. The boundary between the well-compacted red nodular limestones of the lower member (Middle Jurassic) and the marly nodular red limestones of the upper member (Upper Jurassic) is represented by complex hardgrounds representing the Bathonian and Callovian unconformities with iron laminated crusts and macro-oncoids (Figure 4C-F). The studied outcrops are distributed in different tectonic units (within the provinces of Murcia and Alicante): the Quípar Unit (Quípar ( $\left.38^{\circ} 03^{\prime} 10^{\prime \prime} \mathrm{N}, 1^{\circ} 48^{\prime} 15^{\prime \prime} \mathrm{W}\right)$ )), the Lúgar-Corque Unit (Lúgar 62-1 (38 $12^{\prime} 24^{\prime \prime} \mathrm{N}$, $\left.1^{\circ} 10^{\prime} 46^{\prime \prime} \mathrm{W}\right)$, Lúgar $62-2\left(38^{\circ} 20^{\prime} 51^{\prime \prime} \mathrm{N}, 0^{\circ} 55^{\prime} 22^{\prime \prime} \mathrm{W}\right)$ and Caprés $\left.\left(38^{\circ} 14^{\prime} 13^{\prime \prime} \mathrm{N}, 1^{\circ} 07^{\prime} 50^{\prime \prime} \mathrm{W}\right)\right)$, and the Reclot Unit (Rambla Honda- $1\left(38^{\circ} 20^{\prime} 52^{\prime \prime} \mathrm{N}, 0^{\circ} 55^{\prime} 40^{\prime \prime} \mathrm{W}\right)$ and the Rambla Honda-2 $\left(38^{\circ} 20^{\prime} 51^{\prime \prime} \mathrm{N}\right.$, $\left.0^{\circ} 55^{\prime} 22^{\prime \prime} \mathrm{W}\right)$ ). 


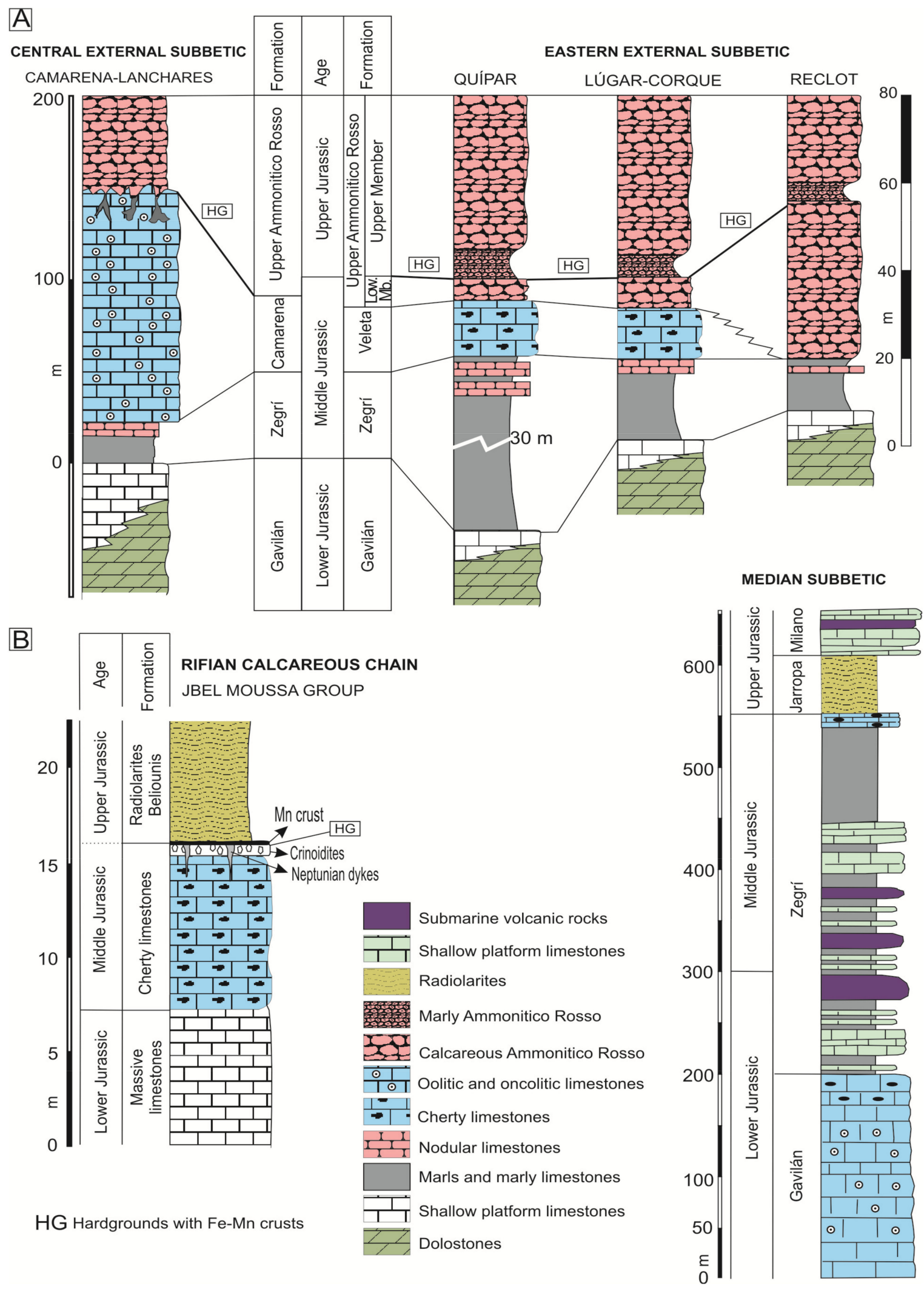

Figure 3. Synthetic stratigraphic sections of the Jurassic in the different tectonic units studied for the External and Median Subbetic (A) and the Rifian Calcareous Chain (B). 

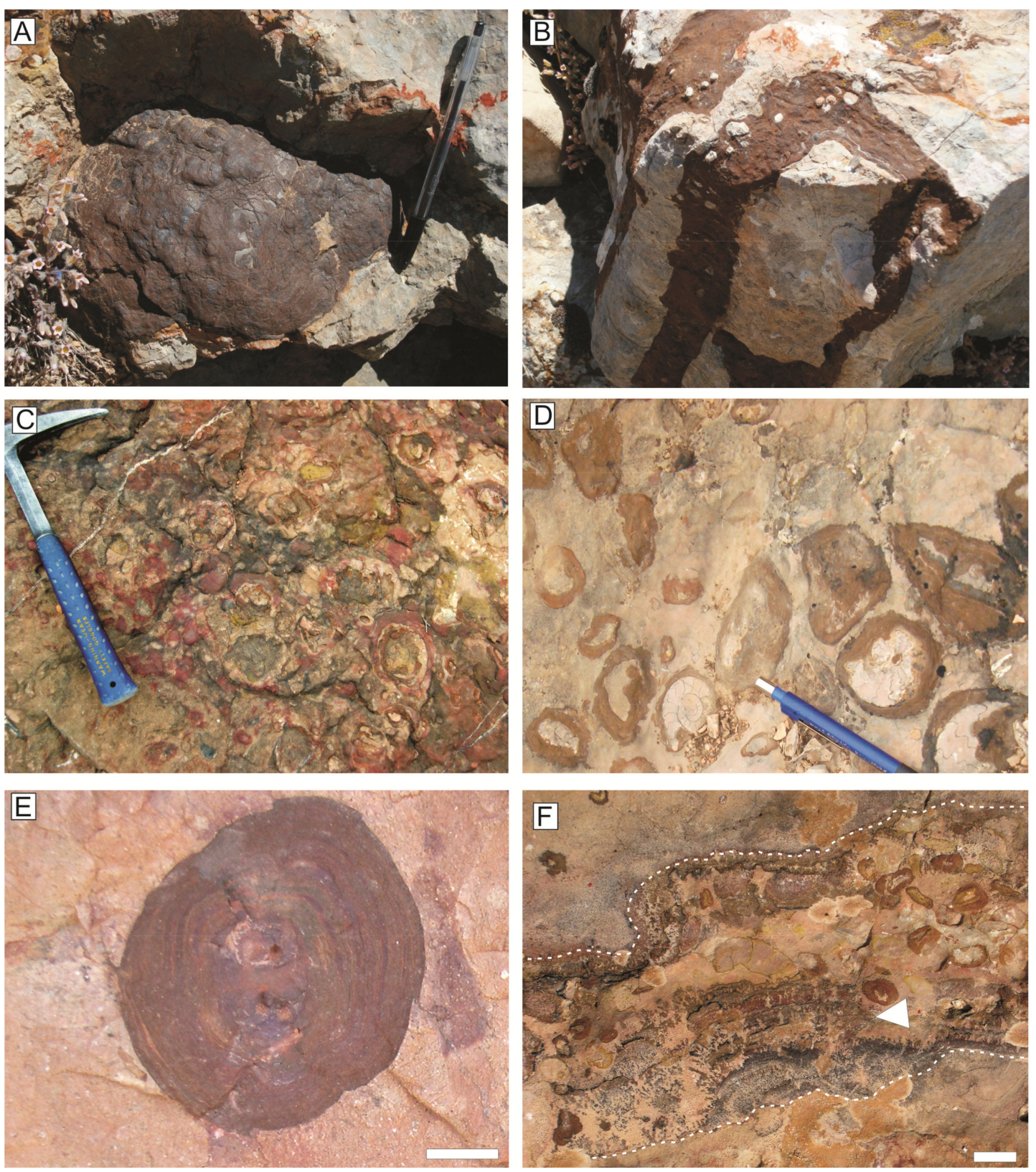

Figure 4. Field view of the iron crusts and macro-oncoids. Central External Subbetic: (A) Iron surficial crust on the Bathonian hardground of the Navahermosa outcrop. (B) Iron endostromatolite growth in a paleokarstic structure (paleokarren surface) of the Navahermosa outcrop. Eastern External Subbetic: (C) Bathonian hardground with iron crusts from the Lúgar outcrop. (D) Ammonoids from the Callovian-Oxfordian hardground with iron coating forming irregular macro-oncoids at the Quípar outcrop. (E) Iron macro-oncoid from the Bathonian hardground of the Rambla Honda outcrop. (F) Feature of a neptunian-dyke with iron endostromatolites in the walls (arrow) in the Bathonian hardground of the Rambla Honda outcrop. Note: scale-bar $=1 \mathrm{~cm}$.

\subsection{Median Subbetic}

The microbialites studied in this domain, which is located between the Internal and External Subbetic, come from Jurassic submarine volcanic rocks (Figure 3, Median Subbetic section). These are pillow-lavas, intercalated between pelagic sediments related to an extensional process of crustal thinning [69,105-107]. The composition of pillow-lavas is transitional alkaline with olivine, Ti-augite, plagioclase (from bytownite to oligoclase), and secondarily Ti-hornblende, biotite, apatite, and Fe-Ti oxides [106,107]. The volcanic and subvolcanic activity generated hydrothermal systems that 
created strong alteration of the igneous and sedimentary host materials and favored the formation of phyllosilicates filling the network of fractures and veins $[108,109]$.

This volcanic formation has a WSW-ENE orientation, and is $5-12 \mathrm{~km}$ wide and around $260 \mathrm{~km}$ long with a maximum thickness of $300 \mathrm{~m}$ [69]. Basaltic pillow-lava flows dominate, interbedded with pyroclastic rocks and pelagic sediments. In particular, the Campotéjar outcrop $\left(37^{\circ} 30^{\prime} 12^{\prime \prime} \mathrm{N}\right.$, $3^{\circ} 37^{\prime} 50^{\prime \prime} \mathrm{W}$ ) placed near to highway A44 at $\mathrm{km} 79$ (Granada province) shows voids among the pillow-lava bodies commonly filled with a variety of material, including broken-up fragments of glassy-lava, sediment materials (limestones and marls), and green laminated crusts involved with calcitic and siliceous cements. The study of these deposits is focused on the green laminated crusts.

\subsection{Rifian Calcareous Chain}

Manganese-rich deposits were studied in the North of Morocco. The studied Jurassic Mn crust is located in the Gibraltar Arc and crops out in the Rifian Calcareous Chain, an area pertaining to the Jbel Moussa Group [63]. The Jbel Moussa Group comprises the typical facies of the Internal Calcareous Chain, with massive white limestones of the lowermost Jurassic, and those of the External Calcareous Chain, with red radiolarites of the Middle and Upper Jurassic [65,66] (Figure 3B).

The studied Mn crust occurs in the Ras Leona mountain, placed $1.5 \mathrm{~km}$ west of Beliounis village $\left(35^{\circ} 54^{\prime} 08^{\prime \prime} \mathrm{N}, 5^{\circ} 24^{\prime} 52^{\prime \prime} \mathrm{W}\right)$. The Mn crust is related to the unconformity between Lower and Upper Jurassic [47]. El Kadiri [110] assigned the Mn crust to the Upper Bajocian after the analysis of radiolarians.

The selected outcrop in the Rifian Cordillera is the best-preserved example with low incidence of diagenesis. Other outcrops with Mn-rich deposits in the Jbel Moussa area are affected by diagenesis and the samples are strongly recrystallized. Observations of original fabrics are not possible and these examples were not studied for this work.

\section{Methods}

The data here reviewed, corresponding to iron crusts, manganese crusts, and green crusts, were obtained from the study of 33 polished slabs, the characterization of 45 thin sections under the petrographic microscope, and also the textural and chemical analysis of a selection of these preparations with scanning electron microscopy (SEM/EDX, backscattered electron images (BSE) and secondary electron images (SE)). X-ray diffractometry was used for all samples to determine the mineral composition. In the case of the green crusts, microprobe analyses of phyllosilicates were performed using wavelength-dispersive spectroscopy (WDX) on an EPMA, and in some cases, due to the very small size of the mineral grains, Cu-grids were also prepared for their chemical analysis in the transmission electron microscopy (TEM). In addition, whole-rock analyses of major elements of the crusts were carried out using X-ray fluorescence (XRF), and for trace elements, inductively coupled plasma-mass spectrometry (ICP-MS). Details about methodology (facilities, measurement conditions, standards, and so on) can be found in Reolid and Nieto [51], Reolid and Molina [104], Reolid et al. [47], and Reolid and Abad [111]. Trace elements and rare earth elements (REE) are compared in some examples with the Post-Archaean Australian Shales (PAAS) [112] as average bulk composition of the upper continental crust, and with the carbonaceous chondrite [113]. Finally, elemental mappings of iron and green crusts have been obtained by XR-microfluorescence M4 Tornado Brucker at the Centro de Instrumentación Científico-Técnica from the University of Jaén. This technique has allowed the determination of the distribution of chemical elements in the microbialites, and in consequence to carry out an interpretation of the geochemical and mineralogical distribution in them.

\section{Results}

In this section, the main textural (morphology and microstructures) and chemical aspects (mineralogy and geochemistry) are shown, in addition to the microbiota features related to the Fe-Mn crusts, Mn crusts, and green crusts. 


\subsection{Iron Microbialite Crusts}

\subsubsection{Texture}

The Fe crusts of the External Subbetic ( $<5 \mathrm{~cm}$ thick) are recorded as crusts on the hardground at the top of the oolitic limestones of the Camarena Fm growing in the walls of neptunian-dykes and sills in the Central External Subbetic (Figures 4A,B and 5). Nevertheless, they are recorded as crusts and macro-oncoids in the top of the lower member of the Upper Ammonitico Rosso Formation in the Eastern External Subbetic (Figure 4C-E).
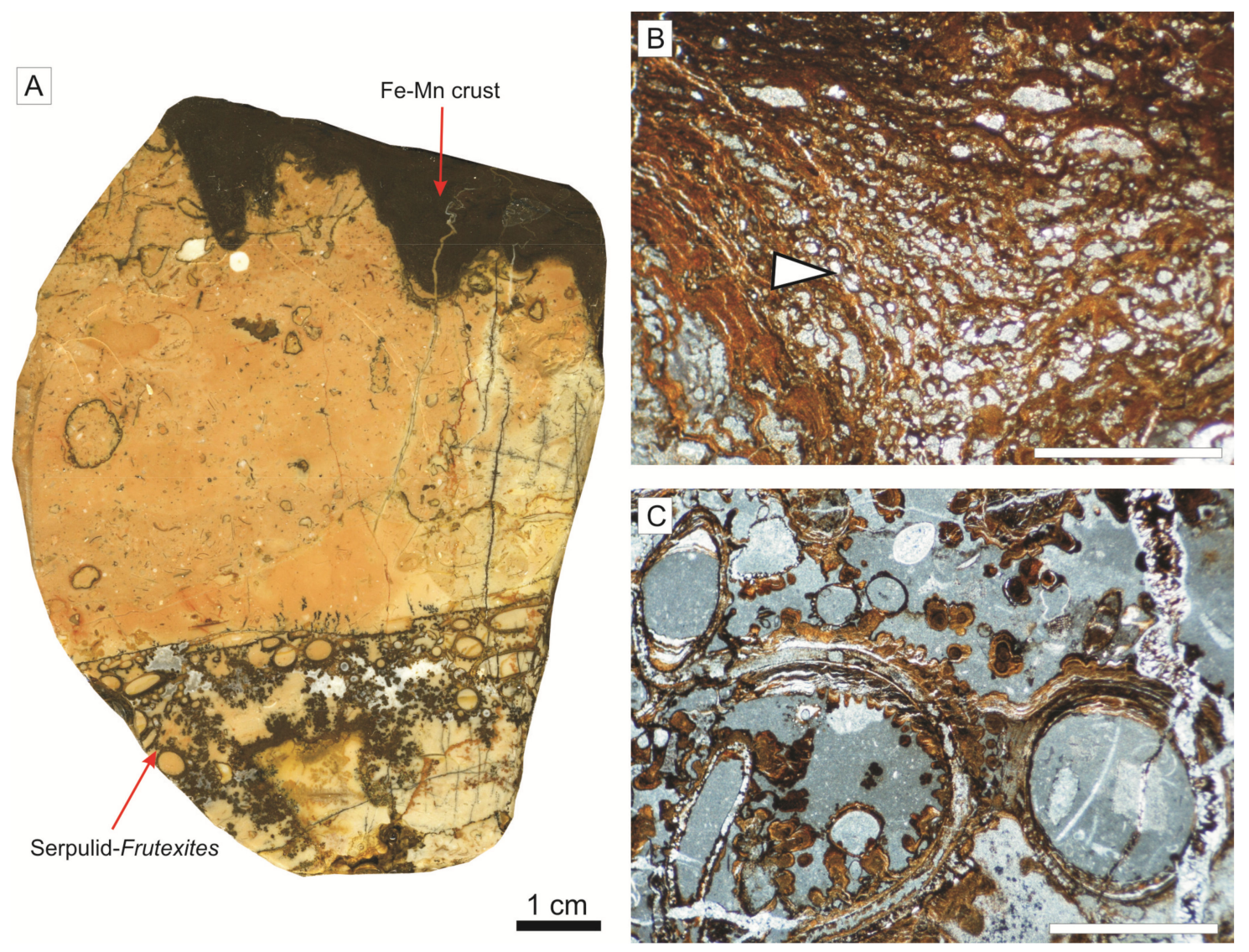

Figure 5. Ferruginous crusts from the Central External Subbetic developed on the complex unconformity of the Middle Jurassic. (A) Polished slab of neptunian-dike with serpulids and Frutexites colonizing the top wall of the cavity. In the upper part of the sample is preserved a paleo-relief fossilized by an iron crust. (B) Planar laminated iron crust with encrusting foraminifera (arrow). Scale bar = $1 \mathrm{~mm}$. (C) Detail of the serpulids colonized by dendritic iron crusts assigned to Frutexites. Scale bar = $1 \mathrm{~mm}$.

In the Central External Subbetic, the top of the oolitic limestones is an irregular surface that resembles classic karstic morphologies, such as kamenitzas and karren surfaces. The infilling of these cavities, which constitutes neptunian-sills and dykes, is a reddish limestone with typical microfacies of the ammonitico rosso facies. Certain iron crusts grew on the walls of these cavities and the smaller cavities are infilled exclusively by laminated iron crusts (Figure 4B). Monty [114] and Burkhalter [115] denominated such cavity and fissure dwelling stromatolites as endostromatolites. This kind of microbial growth was also named in the literature as speleo-stromatolites [116] and cave stromatolites $[8,117]$. The development of the Fe crusts in protected shadow places of the sea-bottom allows them to be called cryptic crusts. 
The crusts developed on the hardground surface present both planar and arborescent morphologies. The planar Fe crusts are characterized by an alternance of clear and dark laminae, whose thickness ranges between 20 and $140 \mu \mathrm{m}$. In the arborescent fabrics, lamination is less evident due to the darker color than in the planar morphologies as a result of the higher MnO content, according to the XR-microfluorescence compositional maps (see Section 5.1.2).

Nevertheless, the most remarkable structures are cryptic crusts associated with a large neptuniansill (3.2 $\mathrm{m}$ high and $13.0 \mathrm{~m}$ long). This neptunian-sill has a pelagic infilling of ammonitico rosso facies from the Callovian to the Upper Tithonian, constituted by wackestones of planktic foraminifera (Globuligerina) and thin-shelled bivalves (Bositra buchi). The crust, around $3 \mathrm{~cm}$ thick, is developed at the top of the cavity and contains a dense aggregate of small serpulids growing downward and coated by thin Fe crusts with an arborescent to dendritic microstructure (Figure 5) [103]. The serpulid tubes have a diameter ranging from 0.29 to $3.22 \mathrm{~mm}$. Thin iron crusts are commonly extended on the outer side of the serpulid tubes with arborescent to dendritic microstructures (maximum $0.71 \mathrm{~mm}$ long and $0.32 \mathrm{~mm}$ wide; Figure 5C).

In the Eastern External Subbetic, three hardgrounds were identified, usually overimposed [118,119]: The Lower-Middle Bathonian hardground, the Middle-Upper Bathonian hardground, and the Callovian-Oxfordian hardground. The Fe crusts and macro-oncoids from these discontinuities are composed by Fe-Mn oxyhydroxides [51,120]. The Fe crusts are characterized by brown and reddish colors, with a 4-5 mm mean thickness (Figure 4C). The iron macro-oncoids are constituted by a core (typically an ammonoid shell or mold) coated by concentric laminae (Figure 4D,E). The size of the iron macro-oncoids ranges between 10-108 $\mathrm{mm}$ (mean size $43 \mathrm{~mm}$ ) and the thickness of the coating reaches $40 \mathrm{~mm}$. The outer shape is sub-rounded, spheroidal to elongate.

The crusts developed directly on the hardground surfaces have a poorly developed laminated fabric, as occurs in the Central External Subbetic, while the macro-oncoids are well-laminated and concentric with respect to the nucleus. The coatings consist of an alternance of clear and dark laminae (20-140 $\mu \mathrm{m}$ thick) with planar and arborescent fabrics (Figure 6). Arborescent and club-shaped morphologies grew from an initial planar lamination (Figure 6C-G). Certain arborescent morphologies evolve to dendritic forms with a dominant growth axis normal to the lamination (finger-like columns). Reolid and Nieto [51] identified a well-developed hierarchy of laminae in different orders of superimposed rhythms in the development of the macro-oncoids. The rhythms can be classified as planar lamina-bearing rhythms (with $0.92 \mathrm{~mm}$ mean thickness) and as arborescent lamina-bearing rhythms (with $2.43 \mathrm{~mm}$ mean thickness). These rhythms resemble those reported in Pacific ferromanganese nodules by Han et al. [121].

The Lower-Middle Bathonian hardground and the Middle-Upper Bathonian hardground present neptunian-dykes in the Eastern External Prebetic [97]. They were open diaclases with planar walls separated at a distance of 0.5 to $37.0 \mathrm{~cm}$ with development of endostromatolites with arborescent morphologies growing from the diaclase walls (Figure $4 \mathrm{~F}$ ). 

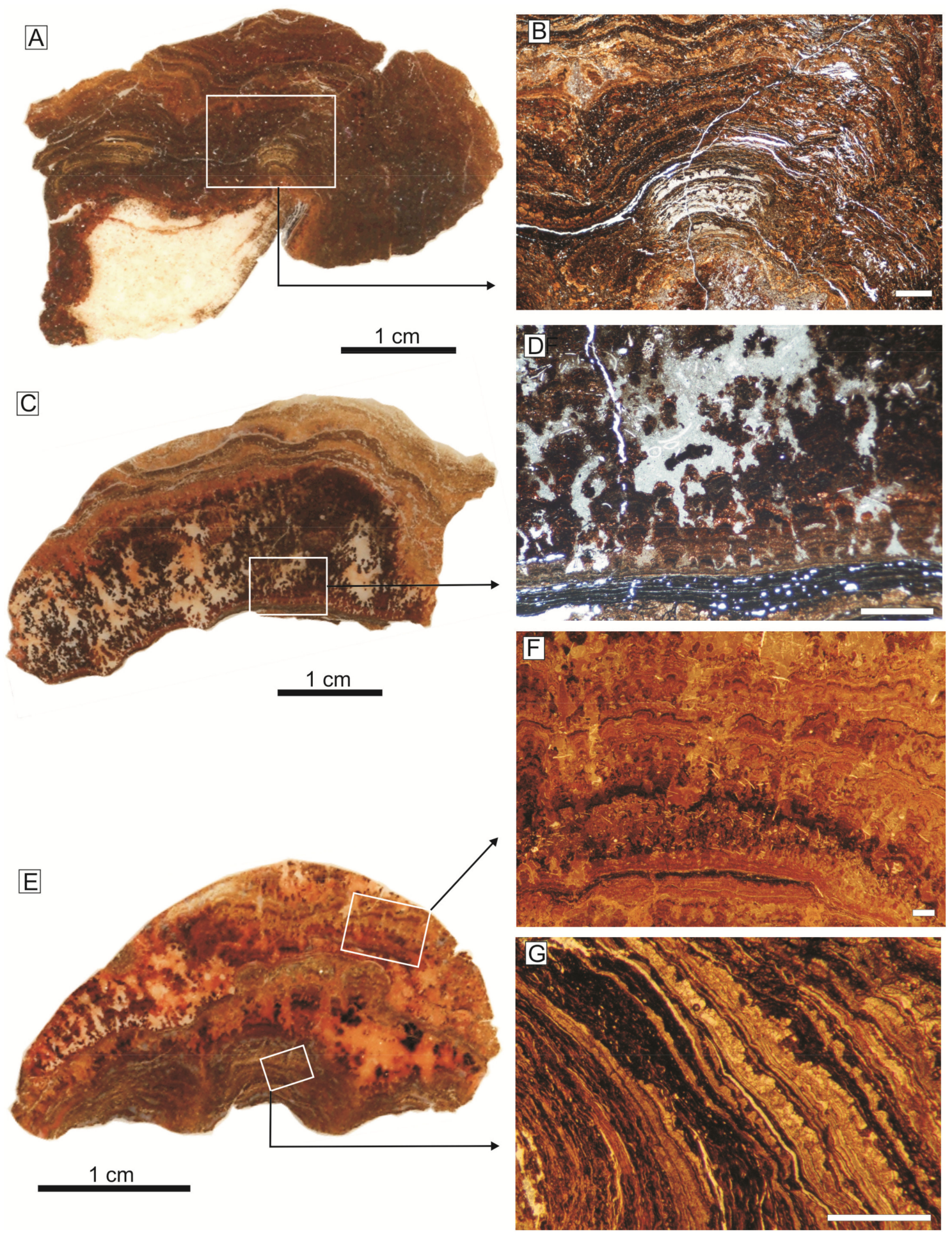

Figure 6. Polished slabs and details of laminated fabrics from the iron crusts of the Eastern External Subbetic. (A,B) Fragment of an iron macro-oncoid from Quípar outcrop (Callovian-Oxfordian hardground) and detail of laminated fabric in thin section. (C,D) Fragment of Fe crust from Lúgar outcrop (Bathonian hardground) with planar and arborescent laminated fabrics. (E-G) Fragment of iron laminated crust (Lúgar outcrop, Bathonian hardground) with planar and arborescent lamina-bearing rhythms. Scale bars for microfacies $1 \mathrm{~mm}$. 


\subsubsection{Mineralogy and Geochemistry}

The crusts studied in the Central External Subbetic are constituted mainly by goethite and calcite, and show a $\mathrm{Fe}_{2} \mathrm{O}_{3}$ content between 13.6 and 19.0 wt. \%, a $\mathrm{MnO}$ content between 3.4 and $6.5 \mathrm{wt}$. \%, and a clearly positive anomaly of $\mathrm{Ce}\left(\mathrm{Ce} / \mathrm{Ce}^{*}=3.11\right.$ average) (Figure 7$)$. The elemental maps of $\mathrm{XR}$-microfluorescence analysis revealed that Mn content is relatively higher in the planar laminae of the top of the hardground than in the endostromatolites.

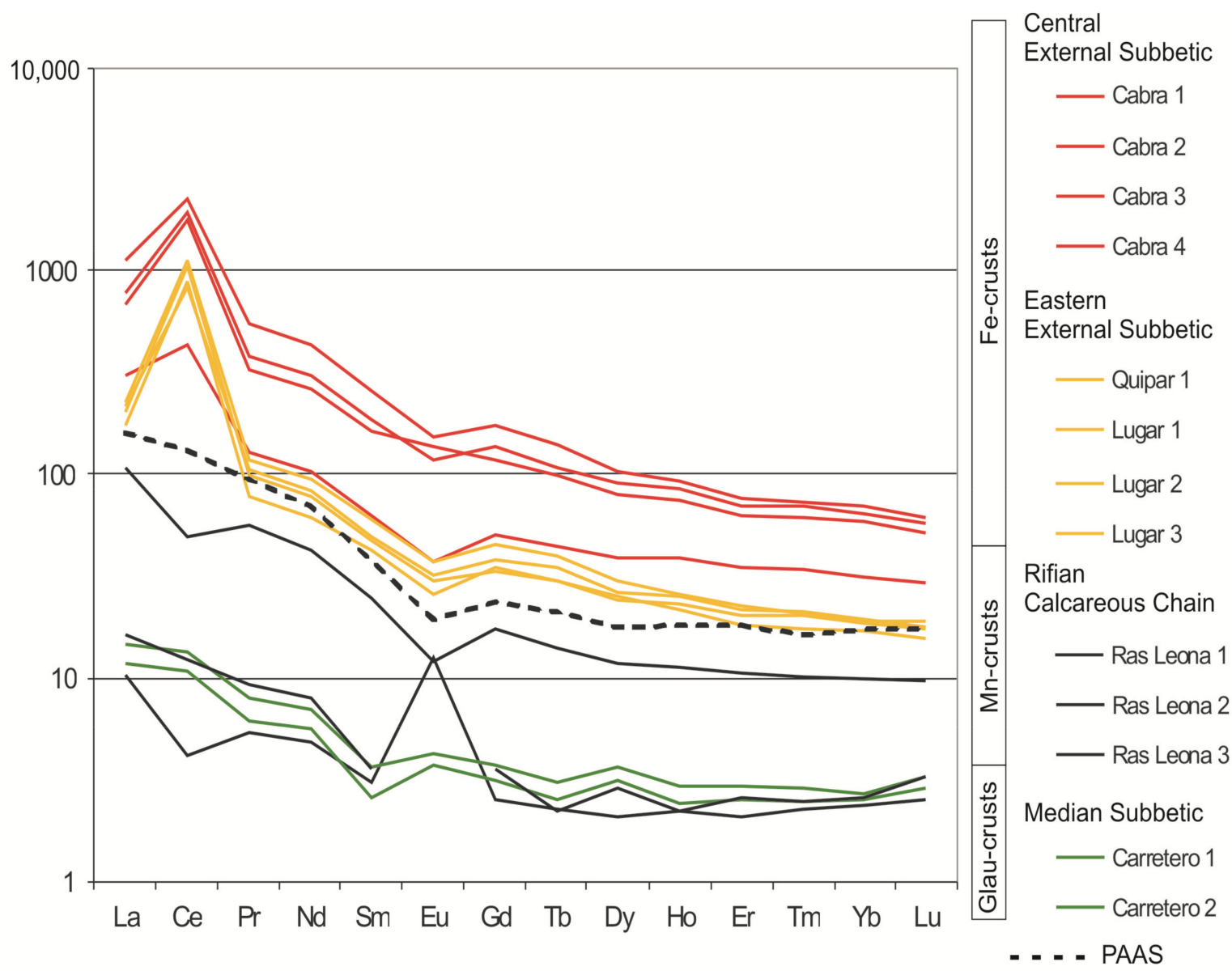

Figure 7. Rare earth elements (REE) of the different microbial crusts studied in this work normalized to the carbonaceous chondrite [113], and compared with the composition of the Post-Archaean Australian Shales (PAAS) [112] representative of the upper continental crust. Observe the positive anomaly in Ce for iron crusts and macro-oncoids from the External Subbetic respect to the PAAS. In the case of the Mn-crust of the Rifian Calcareous Chain (Jbel Moussa Group), a negative anomaly of Ce is observed, whereas Eu shows an anomaly in one sample but the trend in the other samples is parallel to the REE pattern in the PAAS. With respect to the green laminated crusts composed by glauconite micas, the trend is similar than in the PAAS, except for a low negative anomaly in Sm.

In the Eastern External Subbetic, the mineral association, both in iron macro-oncoids and crusts, is made up of goethite, calcite, lithiophorite, and cryptomelane. In general, the $\mathrm{Fe}_{2} \mathrm{O}_{3}$ proportion in crusts and macro-oncoids ranges between 5.7 and $25.4 \mathrm{wt}$. \%. The Mn content is always lower than $1.5 \mathrm{wt}$. \% but variable in detail, as shown in the elemental maps of XR-microfluorescence (Figures 8 and 9). The highest concentrations of $\mathrm{Mn}$ are recorded in arborescent morphologies (Figure 8). Concentric laminae from macro-oncoids show alternance of Fe-rich and Fe-poor laminae (Figures 9C and 10). The Mn-rich laminae are usually coincident with Fe-poor laminae (Figure 9C,D), but Fe content is always higher than Mn content (Figure 10). In addition, elemental maps of XR-microfluorescence for the iron macro-oncoids show isolated laminae rich in $\mathrm{Si}$, $\mathrm{Al}$, and $\mathrm{K}$ that correspond to illite (Figure 9E,F). 
The crusts are enriched in As, Co, Ni, and Sb, while the rare-earth element (REE) content is close to the hydrogenic modern Fe crusts $[122,123]$. These crusts present a positive anomaly in $\mathrm{Ce}\left(\mathrm{Ce} / \mathrm{Ce}^{*}=6.31\right.$ average) (Figure 7).
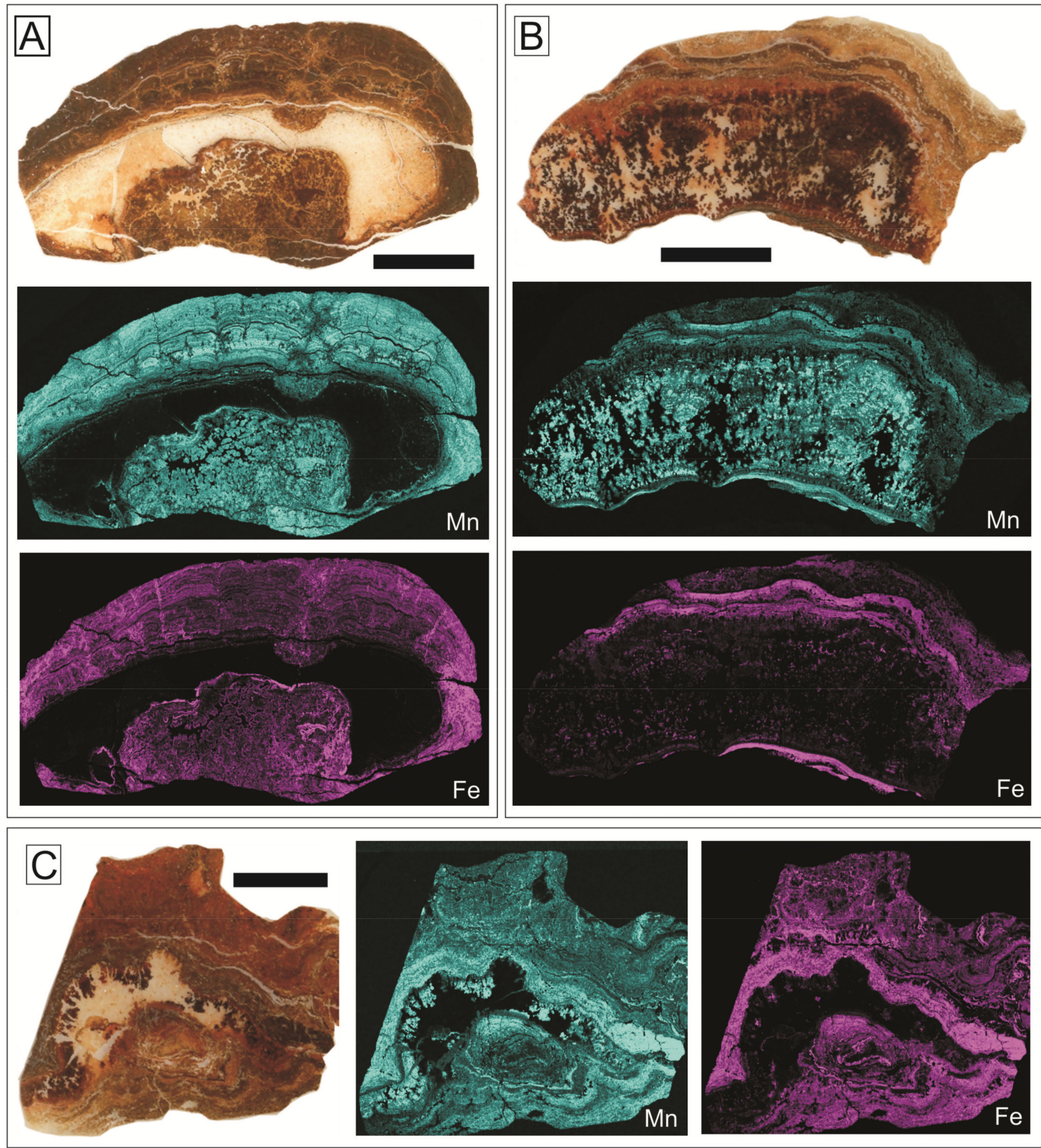

Figure 8. Elemental maps of XR-microfluorescence for Mn and Fe. (A) Part of an iron macro-oncoid developed on an ammonoid fragment from Quípar outcrop (Eastern External Subbetic, CallovianOxfordian hardground). (B,C) Fragments of Fe crust from Lúgar outcrop (Bathonian hardground) with planar and arborescent laminated fabrics. Note that Mn-rich areas correspond to arborescent darker parts. Scale bars $=1 \mathrm{~cm}$. 

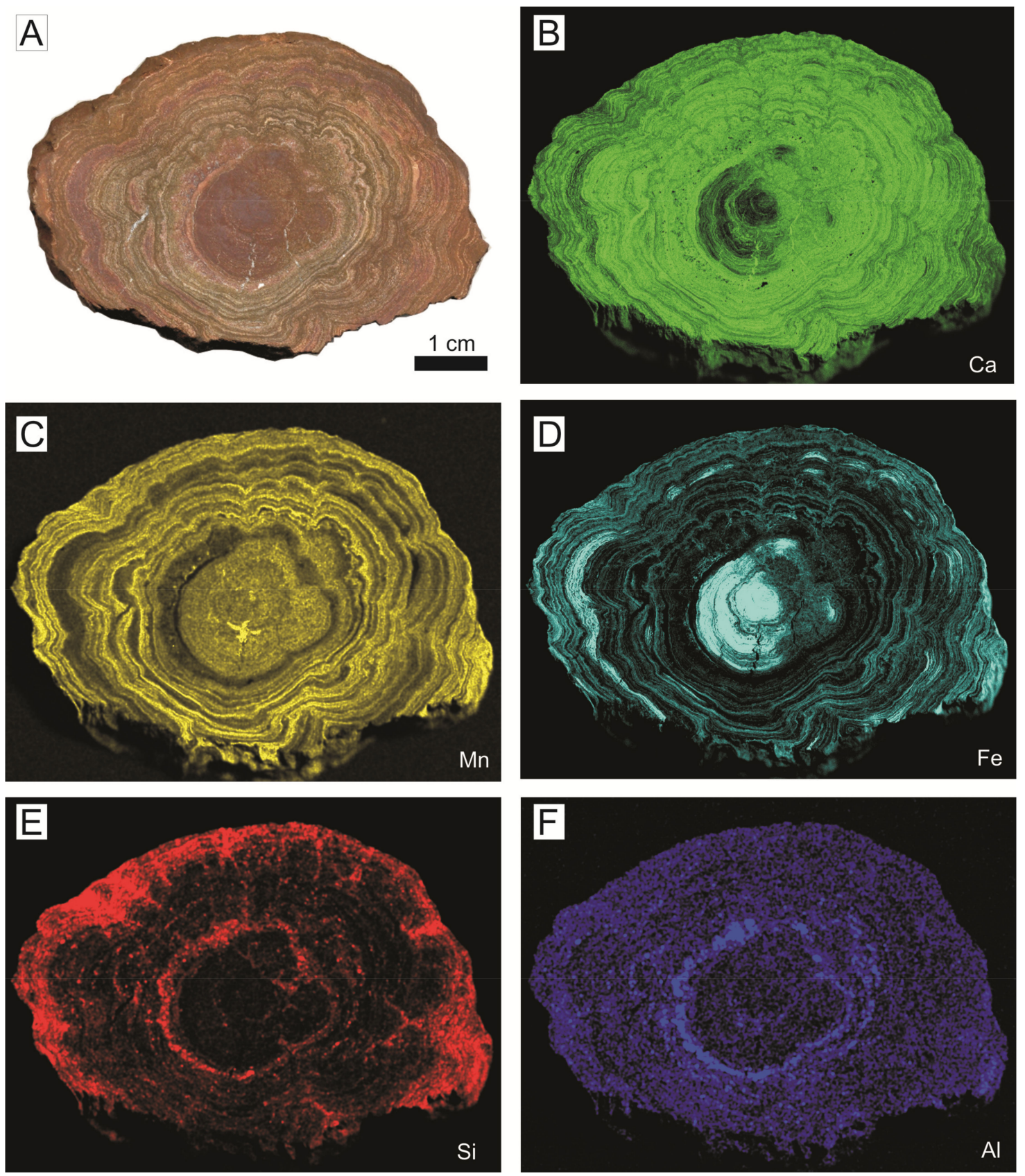

Figure 9. Elemental maps of XR-microfluorescence of an iron macro-oncoid (A) from Lúgar outcrop (Eastern External Subbetic, Bathonian hardground) for $\mathrm{Ca}, \mathrm{Mn}, \mathrm{Fe}, \mathrm{Si}$, and $\mathrm{Al}$ (B-F). Elemental maps for $\mathrm{Mn}$ and Fe show cyclicity in the content, whereas $\mathrm{Si}$ and $\mathrm{Al}$ are concentrated in a concentric clay-rich band. 

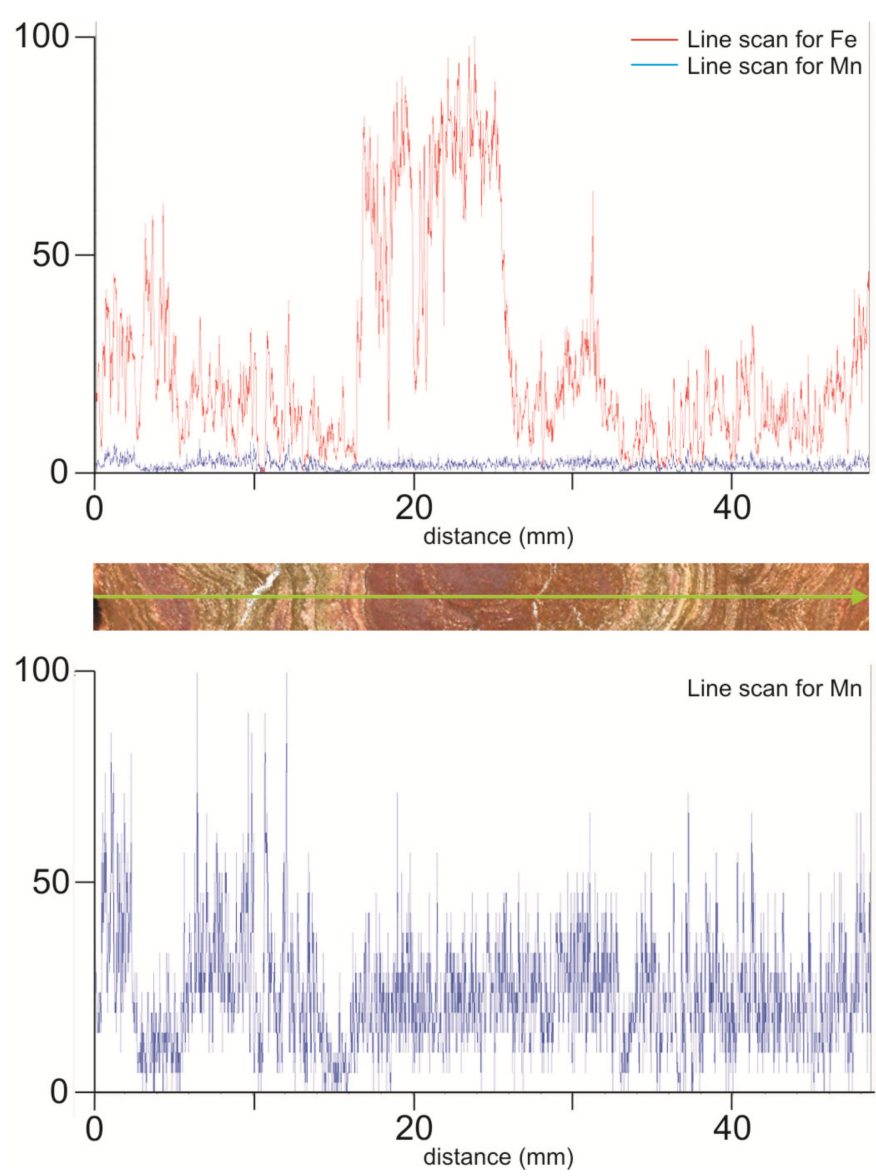

Figure 10. Line scan for Fe and Mn obtained with XR-microfluorescence of a transect of the iron macro-oncoid of the Figure 8 (Note: y-axis indicates number of counts).

\subsubsection{Microbiota}

Planar and arborescent laminated textures identified in the iron laminated crusts and macro-oncoids have been traditionally interpreted as microbialites, mainly in the case of carbonates [1,124-126].

Detailed analysis of the planar laminae under petrographic microscopy, both in the Central and the Eastern External Subbetic, reveals numerous microspheres with spherical to ovoid shapes and an average diameter of $40 \mu \mathrm{m}$ that most likely correspond to microbial microstructures (Figure 11A,B). Thin filamentous microstructures parallel to lamination (probably bacterial sheaths, Figure 11A) are identified in relation to the microspheres, with an average width of $8 \mu \mathrm{m}$. Certain filamentous microstructures, which create fibrillar meshworks, enclose small spheres forming a trichomal arrangement. Microspheres and filaments are infilled by microsparitic cement surrounded (or coated) by Fe-Mn oxyhydroxides. The size and shape of the filamentous microstructures and the microspheres resembles the filamentous cyanobacterium Microcoleus [127]. Thick filamentous and segmented structures (20-30 $\mu \mathrm{m}$ in diameter) have been identified in some parts of the iron crusts and macro-oncoids (Figure 11C), also preserved as carbonate surrounded by Fe-Mn oxyhydroxide. Abundant encrusting foraminifera, such as Vinelloidea and Placopsilina, are also recorded in the Central External Subbetic, and Thurammina, Placopsilina, and Tolypammina in the Eastern External Subbetic.

SEM images allowed us to identify two different types of microbial microstructures made up of calcite with Fe-Mn oxyhydroxide coatings or exclusively of Fe-Mn oxyhydroxides (Figure 12): 

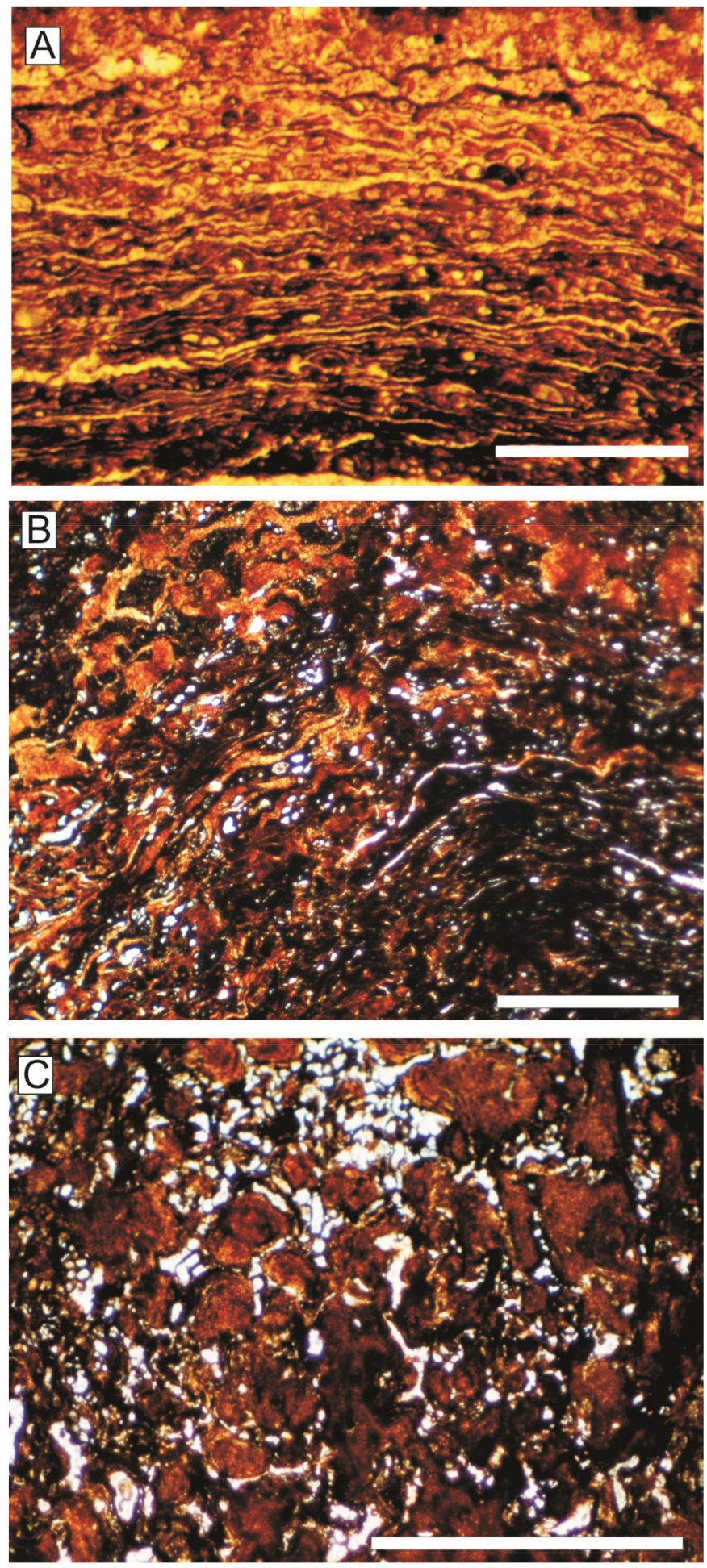

Figure 11. Microbial textures under thin section from iron crusts and macro-oncoids of the Eastern External Subbetic. (A) Detail of planar laminated fabric with fibrillar meshwork arranged with their long axes parallel to the lamination and the presence of microspheres (Lúgar outcrop, Bathonian hardground). Filaments and microspheres are filled by calcitic microsparite. (B) Laminated fabric with fibrillar meshwork and presence of microspheres from an iron macro-oncoid (Quípar outcrop, Callovian-Middle Oxfordian hardground). (C) Segmented filamentous structures from an iron macro-oncoid (Quípar outcrop, Callovian-Middle Oxfordian hardground). Scale bars $=0.5 \mathrm{~mm}$. 

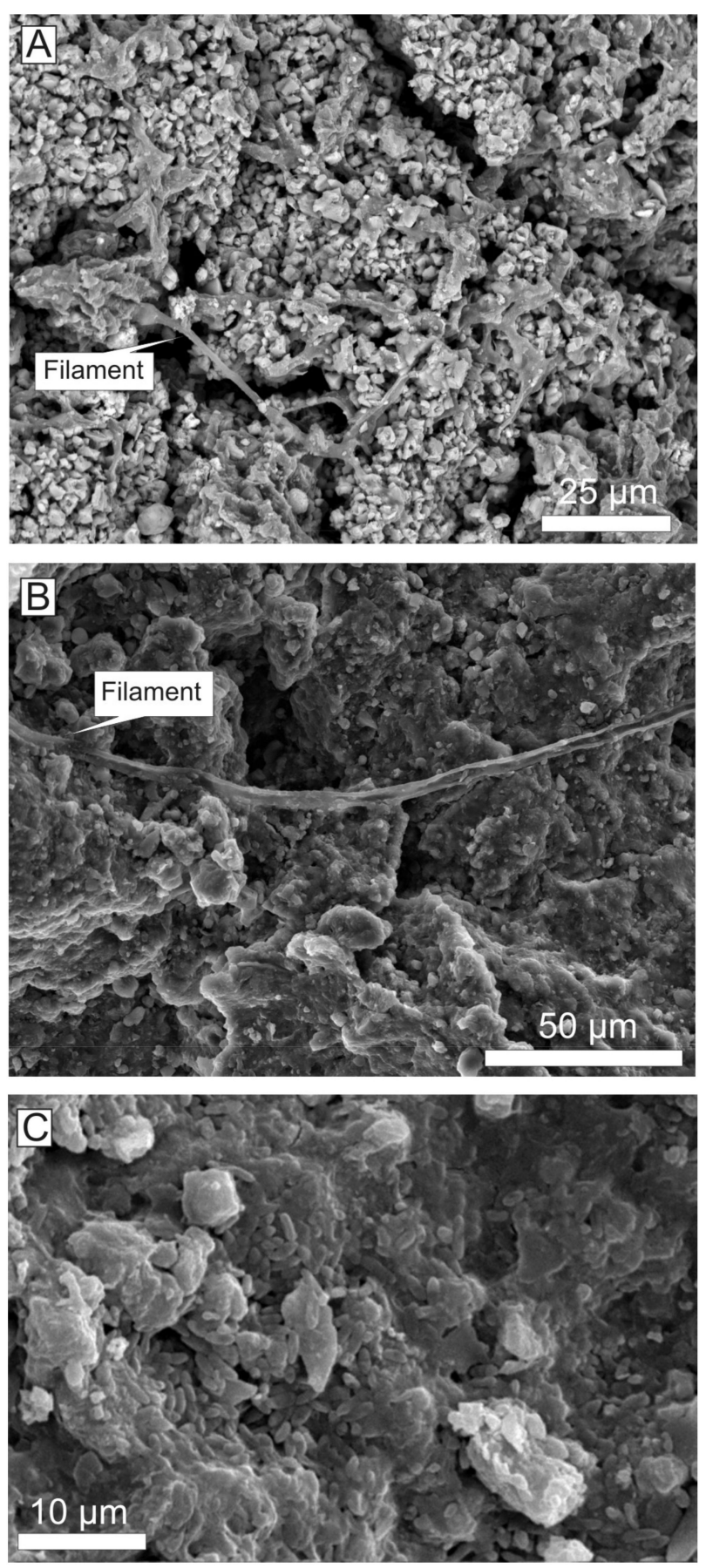

Figure 12. SEM images of fossil microbial structures registered inside iron macro-oncoids (Eastern External Subbetic). (A) Web of branched filaments. (B) Detail of a filament. (C) Aggregates of bacillus-shaped bacteria.

(a) The most abundant microbial structures are dense webs of straight or slightly curved cylindrical filaments with 2-3.5 $\mu \mathrm{m}$ in diameter and having a length around $0.7 \mathrm{~mm}$ (Figures 12A,B and 13A,B). They are branching filaments at various angles and without any evident pattern. These kinds of filaments were interpreted by Reolid and Nieto [51] as related to multicellular hyphae forming a fungal mycelium preserved by the precipitation of Fe-Mn oxyhydroxides.

(b) Other less common microbial morphologies are aggregates of bacillus-shaped forms with $<2$ $\mu \mathrm{m}$ (Figure 12C). 
With respect to the arborescent to dendritic microstructures observed in the iron crusts, macrooncoids, and endostromatolites, they correspond to Frutexites-shrubs. Frutexites has recently interpreted as chemosynthetic bacteria [128], and previously attributed to cyanobacterial origin [129-131] with different types of cyanobacteria involved (Scytonematacean [132]; Rivulariacean [133]; Angulocellularia group [2]). Recently, Guido et al. [134] interpreted the Frutexites from Pleistocene marine cavities as a result of the activity of mesophilic Fe-Mn autotrophic and heterotrophic bacteria. However, filamentous cyanobacteria of Frutexites were not identified in SEM images. Encrusting foraminifera are more common in arborescent structures than in planar laminae with abundance of Bullopora, Thurammina, Tolypammina, and Placopsilina.

With respect to the crusts that grew in the walls of the large neptunian-sill of the Central External Subbetic (Navahermosa outcrop), this is composed of serpulid bundles growing downward with thin iron crusts constituted by arborescent to dendritic microstructures (Figure 5). Other associated organisms are foraminifera, gastropods, and ostracods. The serpulids show microborings progressing from the outer side of the tube. The growth of the serpulid bundles was accompanied by extensive Fe-Mn mineralization, which under SEM, reveals an alternation of thin concave laminae (2.5 to $0.6 \mu \mathrm{m})$ of calcite and goethite (Figure 13C,D). These microstructures were interpreted as Frutexites-shrubs by Reolid and Molina [104]. Sessile foraminifera, such as Bullopora, Thurammina, and Tolypammina, are common attached to both the serpulid tubes and Frutexites columns.
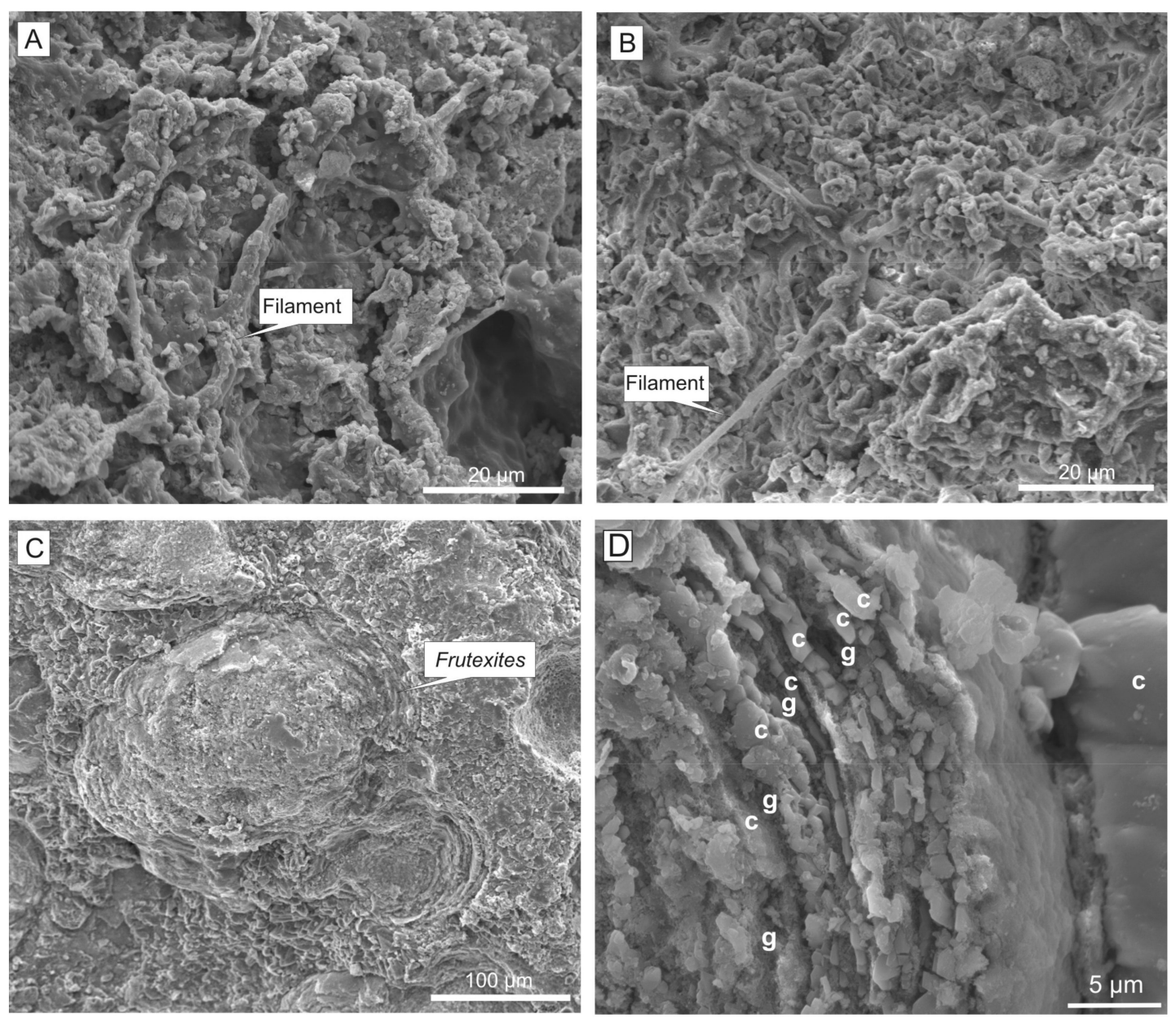

Figure 13. SEM images of fossil microbial structures registered inside of iron crusts developed on the Bathonian hardground (A,B) and Frutexites from neptunian-dykes (C,D) (Central External Subbetic). $(\mathbf{A}, \mathbf{B})$ Webs of branched filaments. (C) General view of Frutexites. (D) Detail of the alternance of calcite (c) and goethite $(\mathrm{g})$ laminae composing the Frutexites-shrubs. 


\subsection{Mn Microbial Crusts}

\subsubsection{Texture}

The discontinuity surface between Middle and Upper Jurassic in the Rifian Calcareous Chain is directly overlain by a black crust 1-10 cm-thick (Figure 14A). The black crust overlies karstic neptunian-dykes formed by the infilling of open diaclases by marine sedimentary material $[47,75]$. The crust presents a poorly developed laminated structure under the petrographic microscope (Figure 14B). Moreover, the opachous black material composing the crust impedes a good observation of the texture. Examination under SEM reveals irregular lamination, 3-20 $\mu \mathrm{m}$ thick. Reolid et al. [47] differentiate two types of planar lamination according to the morphology:

(1) Microbial planar lamination composed by laminae of 3-8 $\mu \mathrm{m}$ mean-thickness and constituted by a dense web of filaments.

(2) Crystalline planar lamination composed by laminae 10-20 $\mu \mathrm{m}$ thick, constituted of small acicular and sheet crystals.
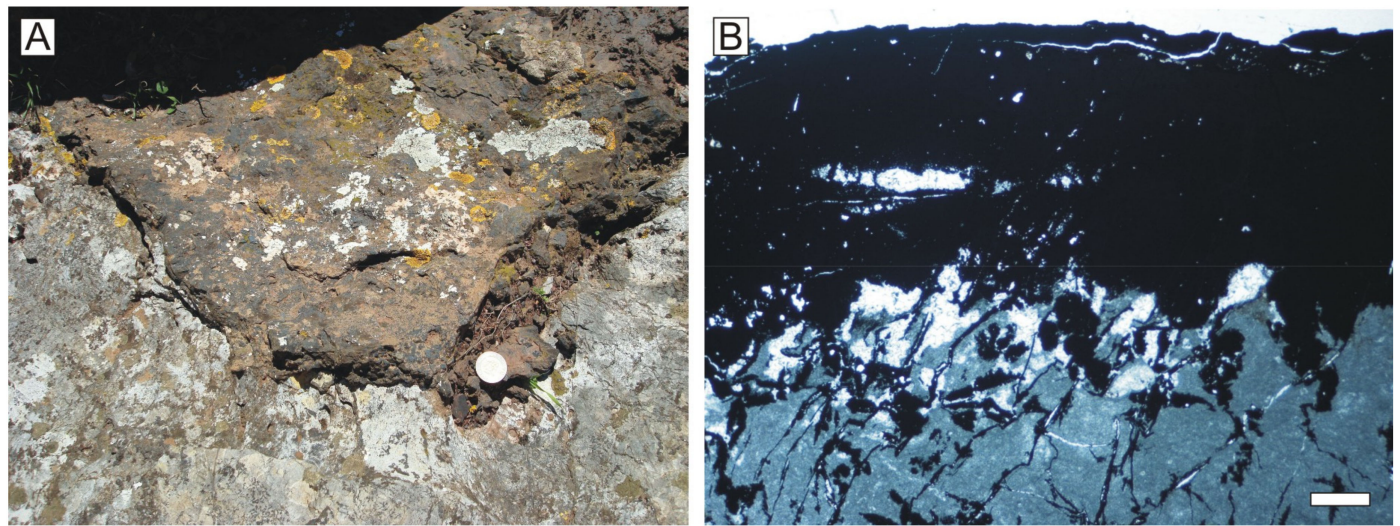

Figure 14. Field aspect of the Mn-crust of the Ras Leona outcrop (Jbel Moussa Group) over the unconformity surface (A) and appearance under thin section $(\mathbf{B})($ Scale bar $=1 \mathrm{~mm})$.

\subsubsection{Mineralogy and Geochemistry}

The bulk chemical composition of the crust consists of high content of $\mathrm{MnO}$ (52.7-72.0 wt. \%), and secondarily $\mathrm{SiO}_{2}$ (2.3-7.3 wt. \%) and $\mathrm{CaO}$ (1.7-5.8 wt. \%). $\mathrm{Fe}_{2} \mathrm{O}_{3}, \mathrm{Al}_{2} \mathrm{O}_{3}, \mathrm{~K}_{2} \mathrm{O}$, and $\mathrm{MgO}$ are $<3.5$ wt. \%. Moreover, the black crust shows substantial enrichments in some trace elements: $\mathrm{Sr}$ (1140 ppm), Ba (2125 ppm), Co (87 ppm), Ni (131 ppm), and Cu (201 ppm), with respect to the bulk composition of the PAAS [111]. The sum of REE in the Mn crust (11 ppm) is very low with respect to the PAAS (183 ppm), the light REE being more abundant than heavy REE. The chondrite-normalized REE patterns, using the CI carbonaceous chondrite [113], show two anomalies: one negative in $\mathrm{Ce}\left(\mathrm{Ce} / \mathrm{Ce}^{*}=0.56\right)$ and in some samples one positive in $\mathrm{Eu}\left(\mathrm{Eu} / \mathrm{Eu}^{*}=4.60\right)$ (Figure 7).

X-ray diffractograms and EDX analyses reveal that the crust is mostly constituted by Mn oxides: Ca-birnessite, cryptomelane, and coronadite (see details in Reolid et al. [47]).

\subsubsection{Microbiota}

Microbial structures of the planar lamination are mainly related to Ca-birnessite rich samples. The filamentous microbial remains built up the Mn crust. Some samples present numerous microbial laminae constituted by superimposed filamentous meshworks (Figure 15A). Crystalline laminae may result from recrystallization of $\mathrm{Mn}$ oxides of the microbial laminae during diagenesis [47]. The SEM analyses of the microbial laminae have revealed five different types of microbial structures mineralized by Mn oxides:

(a) Webs of filaments with dense dichotomous branching (Figure 15A). These are the most profuse microbial structures, seeming to be a dense meshwork with thin, straight to slightly curved cylindrical 
filaments, ranging 2-4 $\mu \mathrm{m}$ in diameter and over $60 \mu \mathrm{m}$ in length. Dichotomous branching is through 90-120 angles. In the best-preserved examples, the filaments are partitioned by cellular cross-walls (septate). In other examples, a detailed analysis of the filament meshwork reveals particular filaments made by ovoid-like microspheres (6-7.5 $\mu \mathrm{m}$ length) forming a trichomal arrangement. Crowded mineralized filaments occasionally form a continuous biofilm. Reolid et al. [47] interpreted a fungal origin, hence filaments could be multicellular hyphae forming a fungal mycelium preserved by Mn oxides.

(b) Rugose simple filaments. These filaments show cellular cross walls and an uncommon branching (at $65^{\circ}$ angle), $<2 \mu \mathrm{m}$ in diameter and $>60 \mu \mathrm{m}$ in length (Figure 15B). Some of them appear as aggregates of grains being unfilled tubes when the diagenesis is not intense.

(c) Smooth simple filaments and biofilms. These microbial structures show smooth surfaces with occasional branching (at $65^{\circ}$ angle) of $2 \mu \mathrm{m}$ in diameter and $>60 \mu \mathrm{m}$ in length, but in some areas they turn to thin smooth veils (Figure 15C).
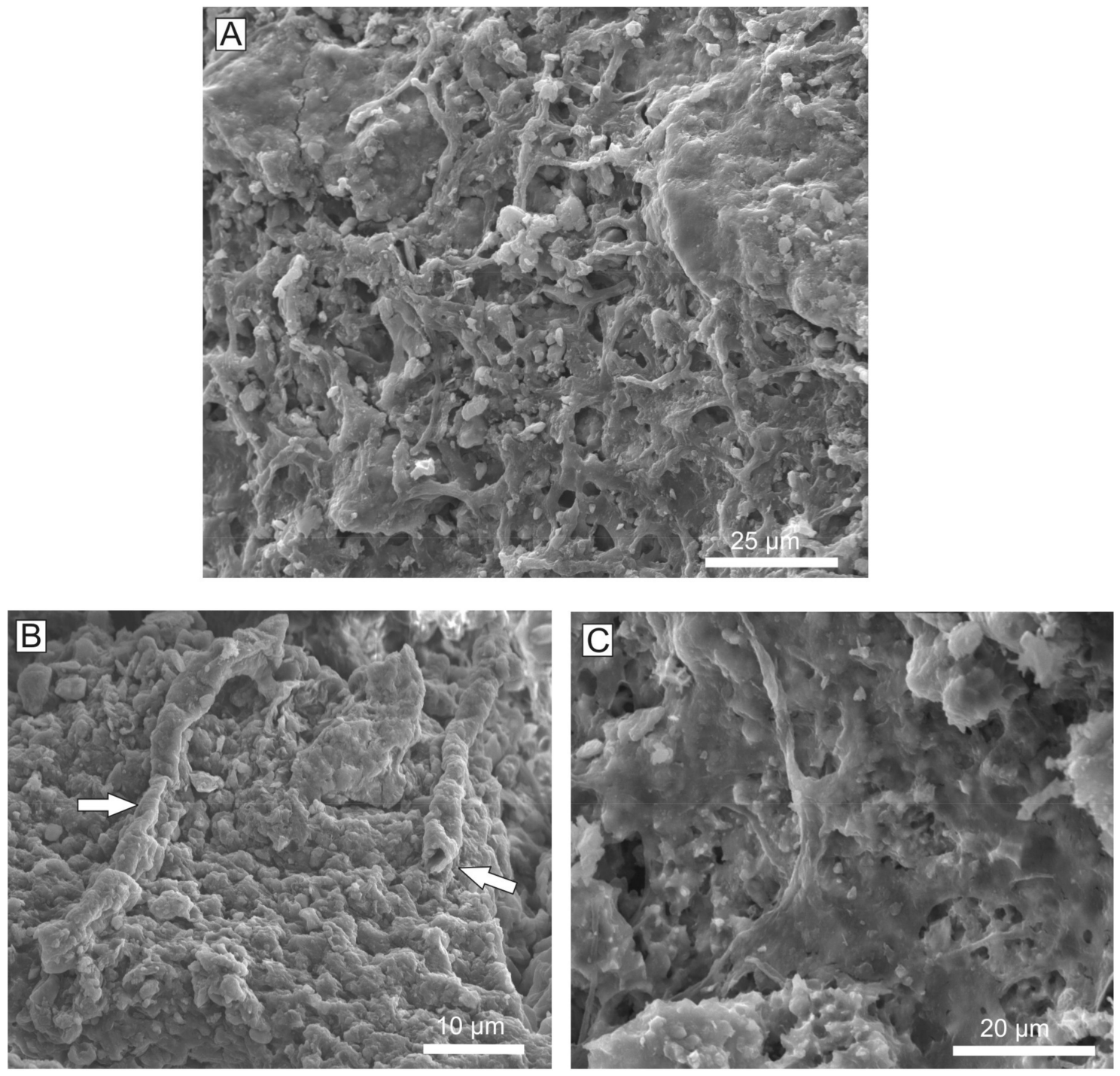

Figure 15. SEM images of the microbial morphologies observed in the Mn crust of Ras Leona outcrop. (A) Lamination formed by webs of branched filaments. (B) Rugose not-branched filaments with cellular cross walls. (C) Veil-like biofilm with some filaments.

(d) Aggregates of bacillus-shaped forms. These ovoidal bodies, with a size of 1.5-3.0 $\mu \mathrm{m}$, are less common and probably related to bacteria (Figure 16A). 
(e) Biofilms with sac-like structures (Figure 16B). These are biofilms with cupuliform and saclike structures (4-7 $\mu \mathrm{m}$ in diameter) having spheric bodies. Many cupules are open and empty, and some spheres are accumulated close to the vessels of the biofilm. In addition, smooth simple filaments described before are close to these structures. The structures could pertain to fungal sporangium [135].
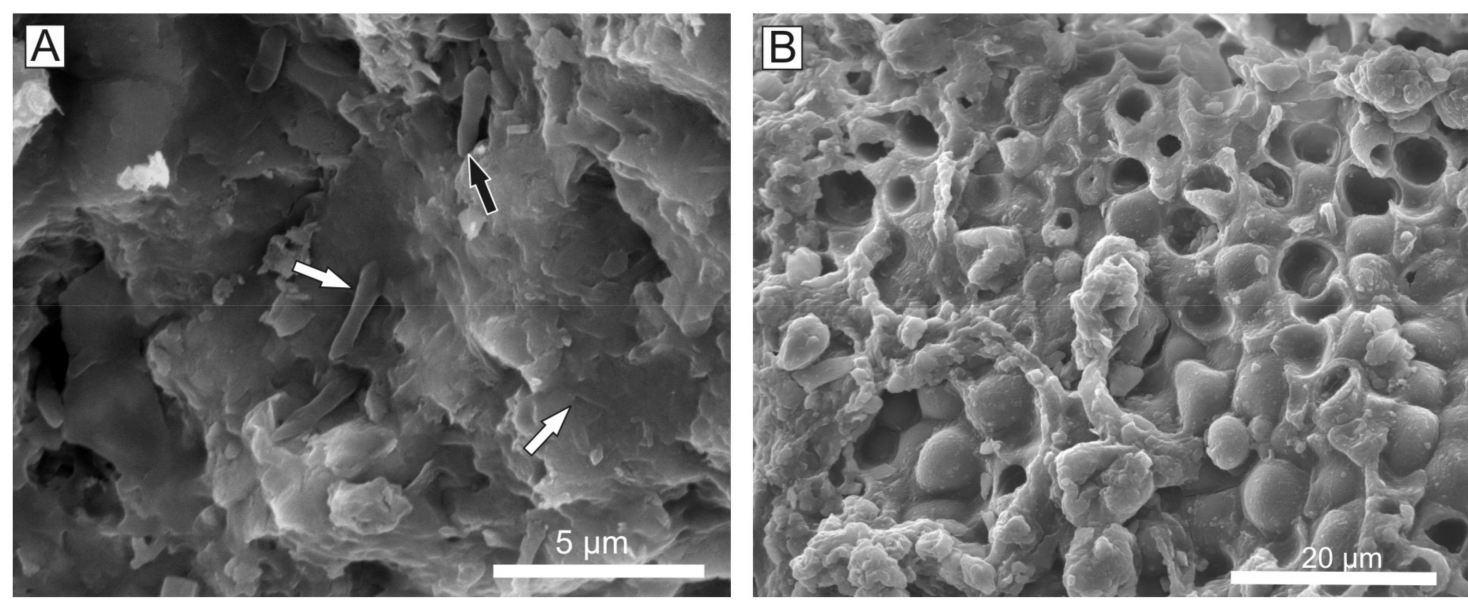

Figure 16. SEM images of microbial structures recorded in the Mn crust of Ras Leona outcrop. (A) Bacillusshaped microbes, generally fused with the Mn minerals (white arrows) but locally well-preserved (black arrow). (B) Biofilms with sac-like structures in the surface resembling a fungal sporangium.

\subsection{Glauconitic Microbial Crusts}

\subsubsection{Texture}

The studied materials are recorded in the inter-pillow spaces, with variable morphology (from irregular to stratiform, Figure 17). These spaces are centimetric, with the largest one reaching $55 \mathrm{~cm}$ in length. The surface of the largest green crust is mamillated. The green laminated crusts grow outwards from the walls of the pillow-lava. The inner parts of the inter-pillow space are filled by transparent crystals (calcite and secondarily quartz, Figure 17D). Quartz commonly occupies the most internal portions of the infilling.

The green laminated crusts generally show planar morphology, with 2-36 mm thickness (mean value of $12 \mathrm{~mm}$ ). In some examples, the calcite and quartz mass occupying the most internal parts of the veins are intersected by green laminated columns ( $<130 \mathrm{~mm}$ length and $<26 \mathrm{~mm}$ in diameter; Figure 17D) stemming from the green laminated crusts, commonly located directly on the walls of the pillow-lava. The presence of green laminated columns gives the mamillated appearance.

Under petrographic microscope and magnifying glass, a laminated texture is observed in the planar crusts and the columns (Figure 18). The laminae are irregular and not densely packed, surrounded by calcitic or quartz matrix. Laminae are 20-60 $\mu \mathrm{m}$ thick and made up of cylindrical filaments with a darker core (dark green or black) and a blue-green thin coat (Figure 18). Some green filaments grow perpendicular to the lamination, measuring $100-450 \mu \mathrm{m}$ in length (Figure 18A,B). Dichotomous and less common trichotomous branching is observed in the perpendicular filaments (Figure 18). The filaments are locally composed of an arrangement of diffuse microspheres.

The analysis of the filaments through SEM-BSE imaging of the thin sections confirms the existence of three parts in the filaments (Figure 19). The dark green core (22-45 $\mu \mathrm{m}$ in diameter) is constituted by very small lath-like crystals $(<1 \mu \mathrm{m}$ length) randomly arranged. The outer part $(8-12 \mu \mathrm{m}$ thick), with blue-green color, consists of a ring of needle-like crystals (lath-like crystals $>5 \mu \mathrm{m}$ length in detail) disposed as a coating around the inner part, with druse arrangement (oriented perpendicular to the filament; Figure 19). In addition, SEM-BSE images show the generalized presence of voids (3.5 to $8.5 \mu \mathrm{m}$ in diameter) at the center of the filaments (Figure 19). The transition between inner and outer 
parts is characterized by a progressive orientation of the crystals through palm-tree branches and progressively larger crystals.
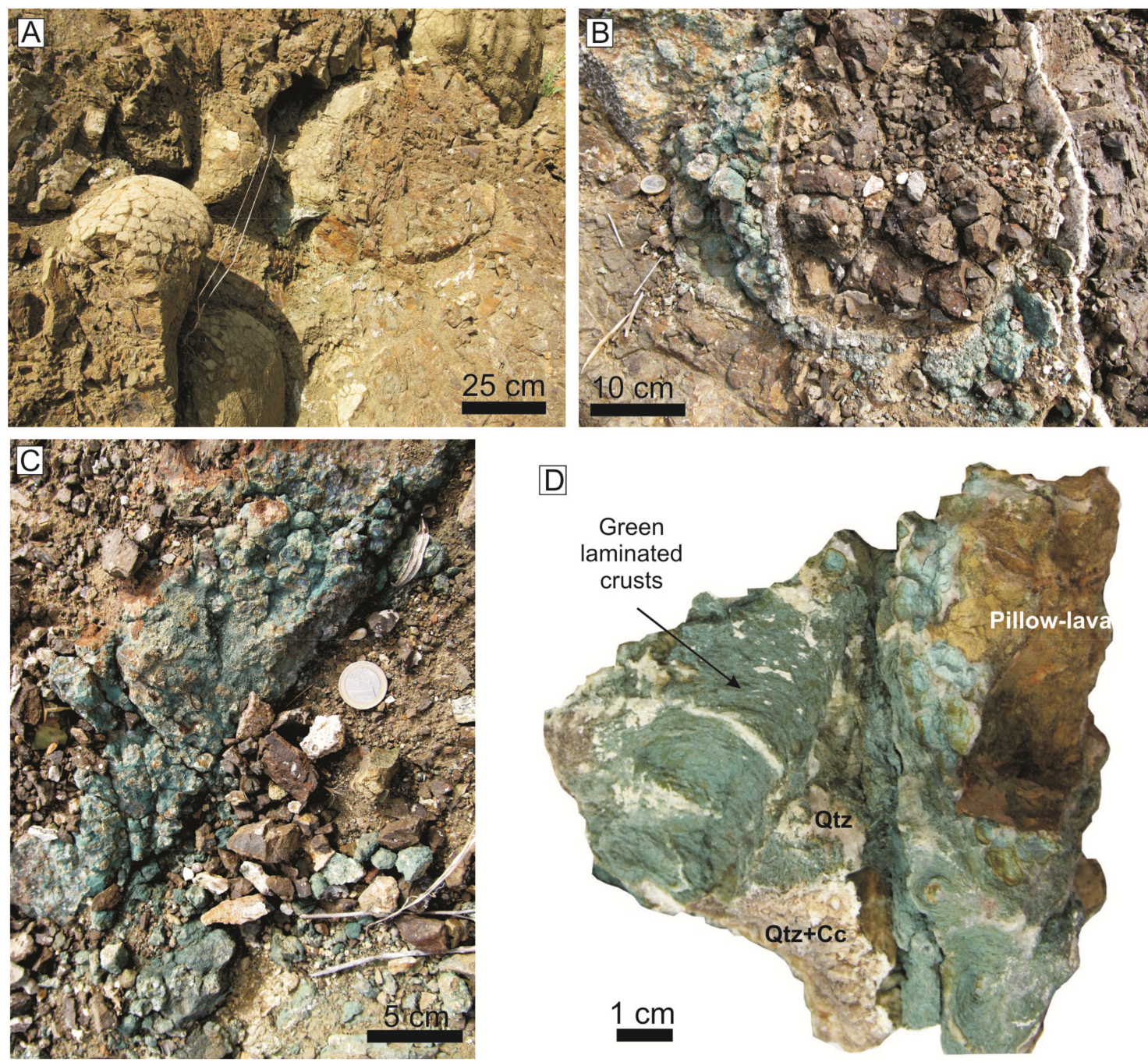

Figure 17. Jurassic pillow-lava of the Median Subbetic (A) and green crusts occupying the spaces between pillow-lava bodies (B). Note the mammillated appearance of the green crusts (C) favored by the presence of green laminated columns (D). Cc: calcite, Qtz: quartz.

Secondary electron and TEM images of Reolid and Abad [111] show that the needle-like coating of the filaments actually consists of idiomorphic lath-like crystals $<10.5 \mu \mathrm{m}$ long and $<0.8 \mu \mathrm{m}$ wide. Some lath-like crystals present clay-flake morphology and small filamentous to coccoid-shaped forms, with $<0.5 \mu \mathrm{m}$ length and $0.1 \mu \mathrm{m}$ width. In addition, a characteristic irregular film covers the green crystals in some parts of the analyzed samples, locally showing filament-like structures ( 15 $\mu \mathrm{m}$ length, $<1 \mu$ m diameter). 

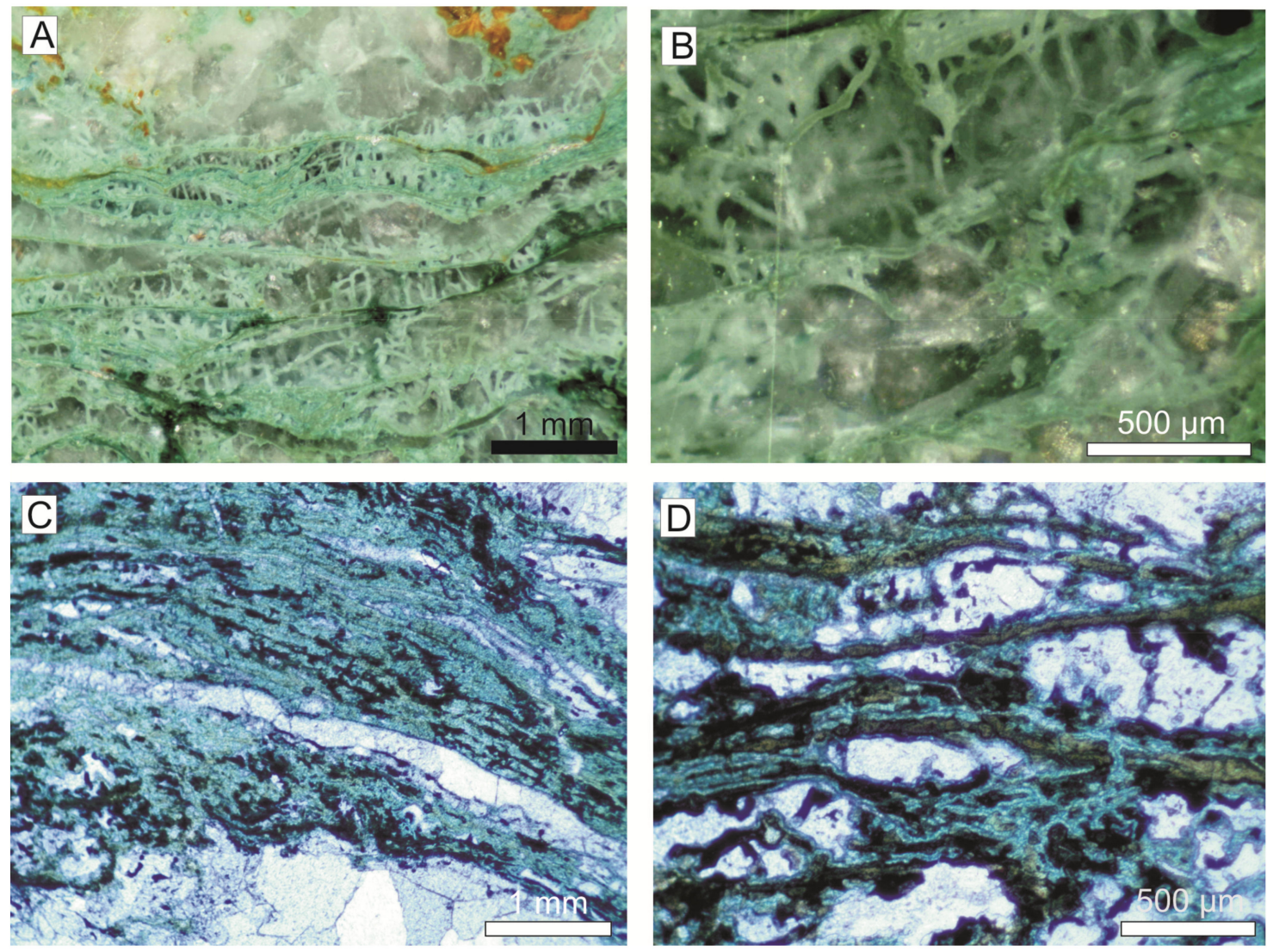

Figure 18. Filament structures from green laminated crusts observed by magnifying glass on polished slabs (A,B) and petrographic microscopy on thin sections (C,D). (A,B) Transversal section of a green laminated crust surrounded by calcite with the presence of planar filamentous green laminae and perpendicular branching filaments. (C,D) Mesh of green filaments composing the lamination. Note that blue-green material corresponds to glauconitic micas (glauconite and celadonite) and dark green to black material corresponds to smectite (saponite).

\subsubsection{Mineralogy and Geochemistry}

The XRD patterns of oriented aggregates corresponding to the green masses show glauconitic mica (glauconite and celadonite), calcite, and a small amount of smectite (saponite according to Reolid and Abad [111]).

The analyses of the green crusts are characterized by a high loss on ignition (LOI) from 18.9 to 23.8 wt. \%. The major elements (in oxides) range from $27.8-34.4$ wt. \% for $\mathrm{SiO}_{2}, 20.2-26.7 \mathrm{wt}$ \% for $\mathrm{CaO}$, 8.7-10.4 wt. \% for $\mathrm{Fe}_{2} \mathrm{O}_{3}, 4.6-5.5$ wt. \% for $\mathrm{Al}_{2} \mathrm{O}_{3}, 4.4-5.4$ wt. \% for $\mathrm{K}_{2} \mathrm{O}$, and 3.3-3.9 wt. \% for $\mathrm{MgO}$. The high values of $\mathrm{CaO}$ compared with literature data of glauconites [136] are related to the presence of calcite in the whole-rock sample of the green deposits. The elemental maps of XR-microfluorescence analysis revealed that $\mathrm{Fe}$ and $\mathrm{K}$ content is relatively higher in the green laminae than in the surrounding minerals (Figure 20).

A detailed micro-chemical analysis of the green crusts allows the characterization of glauconitic micas and the detection of clear differences between the chemical composition of lath-like crystals composing the outer coating of the filaments and the inner part [111]. The dioctahedral micas corresponding to the outer lath-like crystals show lower Fe (0.62 atoms per formula unit (a.f.u.)) and higher $\mathrm{Al}(0.81$ a.f.u.) and $\mathrm{Mg}$ (0.69 a.f.u.) contents (average values) than the inner crystals ( $\mathrm{Fe}=0.98$ a.f.u; $\mathrm{Al}=0.69$ a.f.u.; $\mathrm{Mg}=0.54$ a.f.u.). In addition, the outer crystals are characterized by interlaminar contents close to 1 a.f.u., whereas the inner glauconites are always $<0.85$ a.f.u. These data, as well as the lower content of tetrahedral $\mathrm{Al}$ in the outer micas, clearly corroborates the existence of 
two dioctahedral mica populations, being the inner micas glauconites and the outer ones-celadonites (Figure 19B,C). According to Tóth et al. [137], celadonite is the most evolved stage of glauconitization.
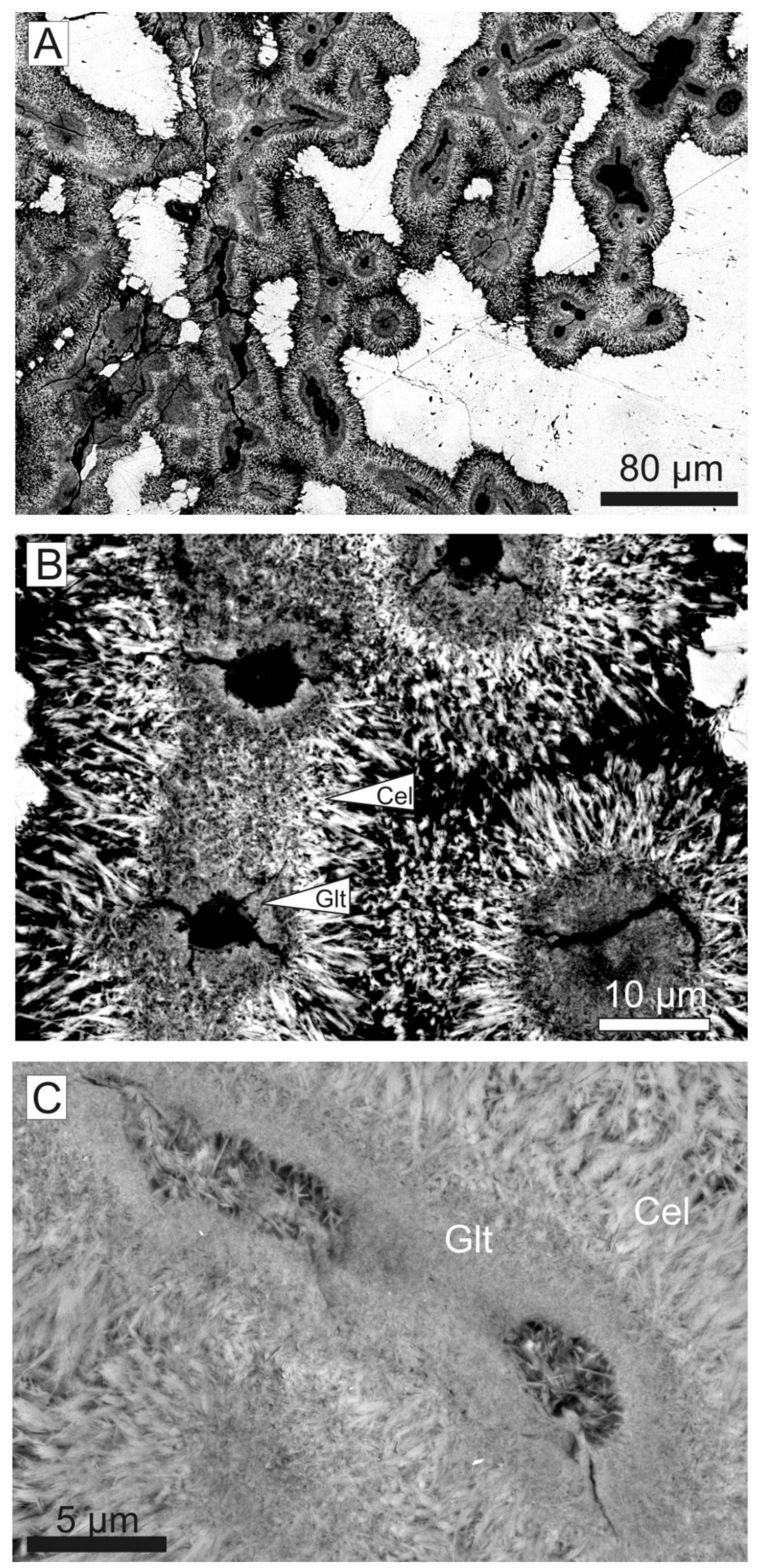

Figure 19. Filaments composing the green laminated crusts observed under SEM-BSE. (A) General view of filaments with transversal and longitudinal sections. (B,C) Detailed views of the filaments with differentiation of three parts, with the inner one being a void, the intermediate one homogeneous glauconite (arrow Glt), and the outer one composed by needle-like crystals of celadonite (arrow Cel). 

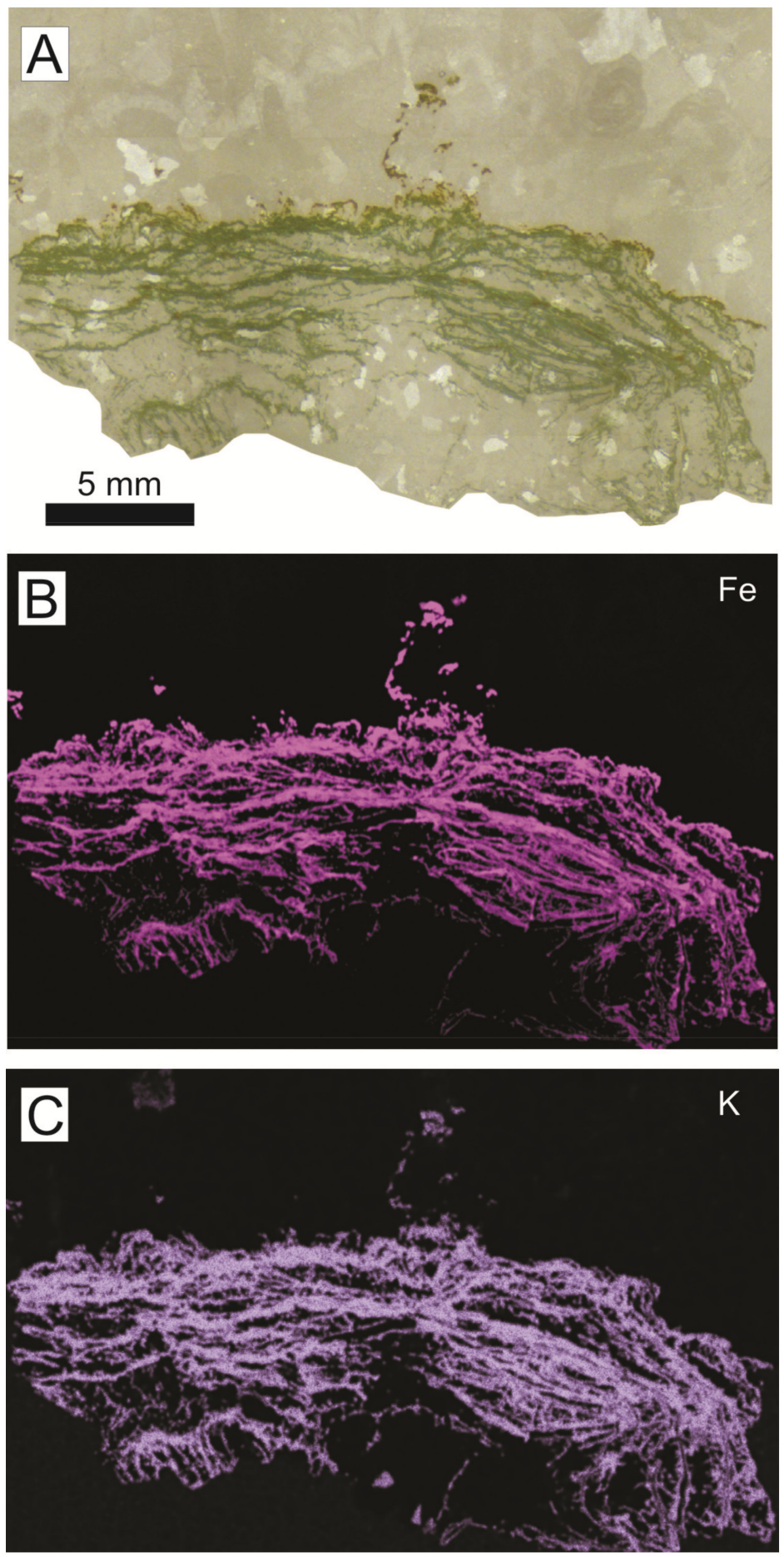

Figure 20. Original aspect (A) and elemental maps of XR-microfluorescence for $\mathrm{Fe}(\mathbf{B})$ and $\mathrm{K}(\mathbf{C})$ that illustrate the concentration of these elements in the green crust composed by glauconitic micas.

\subsubsection{Microbiota}

The record of filaments and coccoid-shaped forms at different scales points to the potential implication of BMC in the growth of the green laminated crusts. The laminated texture is given by the dense web of branched filaments (Figure 18). Large filaments are parallel among themselves and produce the laminated appearance. Short filaments grow up perpendicular from the large filaments of different laminae. The glauconite coated the organic microbial filaments now represented by the record of voids in the center of the filaments composing the green laminated crust (Figure 19). In addition, the 
film showing filament-like structures covering the glauconitic crystals in some of the samples analyzed would correspond to biofilm.

\section{Interpretation}

Four different settings of non-carbonate microbial crusts can be differentiated in the Jurassic of the Betic-Rifian Cordillera: surficial Fe-Mn crusts and macro-oncoids related to hardgrounds, cryptic Fe-Mn crusts related to paleocavities, surficial Mn crusts related to hydrothermal vents, and glauconitic crusts linked to hydrothermal phase of the submarine vulcanism.

\subsection{Iron Crusts and Macro-Oncoids on Hardgrounds}

The described Fe-Mn crusts are mainly formed by goethite, which has survived more than $155 \mathrm{Ma}$ of burial history without being replaced by hematite (more stable than goethite during burial). This confirms the excellent preservation of the studied microbialites and the low incidence of diagenesis. The presence of foraminifera encrusting the laminae, as well as the relation with the grains in the microfacies, confirm that these crusts are hydrogenetics and not the result of the diagenesis. Martín-Algarra and Sánchez-Navas [138] and Reolid and Nieto [51] interpreted the formation of Jurassic iron laminated crusts and macro-oncoids from the Subbetic as related to the chemo-organotrophic behavior of the BMC. Iron oxides can precipitate as a result of the direct metabolic activity of microbes, or else as a consequence of passive sorption and nucleation reactions $[32,139]$. Many authors have interpreted diverse types of eubacteria, inducing Fe and Mn mineralization [7,40]. Fe- and Mn-oxidizing bacteria, both chemoheterotrophic bacteria (such as Sphaerotilus, Leptothrix, and Siderocapsa) and mesophilic autotrophic (such as Acidithiobacillus ferrooxidans and Leptospirillum sp.) are known to induce the precipitation of Fe-Mn oxyhydroxides under acidic and neutral conditions, where $\mathrm{Fe}^{3+}$ and $\mathrm{Mn}^{4+}$ are soluble [40,140,141]. However, Dahanayake and Krumbein [39] affirmed that iron-secreting microbial mats are predominantly fungal in origin. Moreover, the presence of Frutexites-like forms is commonly associated with Fe-Mn crusts, and they are inferred as chemosynthetic and cryptobiontic microorganisms $[128,134,142,143]$.

The Mn content of some concentric bands in the macro-oncoids is also indicative of biogenic activity in this kind of deposit (Figure 9). Ehrlich [144] and Krumbein [27] suggested the impact of microbes in the reactions of Mn in deep-sea manganese nodules, whereas Schaefer et al. [145] propose that $\mathrm{Mn}$ precipitation is biogenically controlled in shallow water oncoids. In recent environments, efficient precipitation of $\mathrm{Mn}$ ( 4 to 5 orders of magnitude more effective than abiotic precipitation) from natural water depends basically on the presence of Mn-oxidizing eubacteria [40,146-148].

Specific Fe and Mn enrichment by microbes highlights the importance of microbial biocoenoses as catalyzers, also serving as specific traps of these elements [7,37-40]. Fe and Mn are concentrated by extracellular traps in the microbial wall favored by the increase of the chemical gradients between the surrounding sea-water environment and the cytoplasm. The microbial sheaths are preserved coated with nanocrystalline goethite, as reported by Ghiorse and Ehrlich [149] and Salama et al. [7]. In the studied macro-oncoids, the earlier presence of mucilaginous substances around the microbes can be interpreted by the presence of fossil fibrillar meshworks. The mucilaginous substances worked as an iron chelating compound (siderophore ligands, organic molecules that scavenge $\mathrm{Fe}^{3+}$ from seawater and deliver it to the cell surface $[32,150])$. Authigenesis occurred by means of the Fe and Mn formerly enriched by the siderophores as amorphous precursor stages that could later be precipitated as Fe-Mn oxyhydroxides, probably as colloids. The hydrogenetic mechanism of formation of crusts and macro-oncoids means that they also sequester large quantities of metals from ambient deep waters. In modern ferromanganese nodules and ferromanganese crusts, the physicochemical properties of the Fe-Mn colloids under oxic conditions make them excellent at scavenging dissolved metals from deep seawater, such as $\mathrm{Ni}, \mathrm{Cu}, \mathrm{Co}$, and REE [30]. In this sense, the Ce enrichment resulting in a positive anomaly might be adequately explained by oxidative scavenging of $\mathrm{Ce}^{4+}$ from normal seawater by Fe-Mn oxyhydroxides formed by BMC [11]. The hemipelagic swells of the External 
Subbetic were favorable settings for microbially mediated authigenesis due to the sediment-starved conditions [97,118].

The presence of microorganisms, such as fungi and encrusting foraminifera, with microbial biofilms closely resembles commensalism. The biofilms served as a food source for the encrusting foraminifera and fungi, while the bacteria and fungi took advantage of the nutrient-rich foraminiferal excretions. Veillette et al. [151] analyzed the sessile foraminifera from modern Mn nodules and inferred that food particles could be obtained from microbial films of the nodule surface. According to Gooday and Haynes [152] and Lipps [153], encrusting foraminifera are passive herbivores that presumably feed on bacteria.

\subsection{Cryptic Fe-Mn Frutexites Crusts}

The walls of submarine cavities and fissures formed related to the Middle-Upper Jurassic unconformity in the Central External Subbetic were a suitable place for colonization by serpulidFrutexites assemblages. In the examples of the neptunian-dykes from the Eastern External Subbetic, the endostromatolites are only composed by Frutexites. The surface of the Frutexites is colonized by encrusting foraminifera and confirm the hydrogenetic origin.

The serpulids are epibionts with photophobic behavior [124,154]. The serpulid tubes were colonized by Frutexites. Similar authigenic precipitation of Fe-Mn oxyhydroxides on serpulids recorded from cryptic environments was interpreted on modern hard surface fauna by Toscano and Raspini [155] and from Jurassic examples by Schlögl et al. [156].

The record of Frutexites is usually related to Fe-Mn oxyhydroxides [51,128,131,134,142,157-159]. The type of microbe involved in Frutexites, however, is unclear being frequently assigned to a cyanobacterial origin $[2,131,132]$ or interpreted as a chemosynthetic and cryptobiontic microorganism $[128,134,142,143,160]$. Böhm and Brachert [142] related the record of Frutexites with scarce light availability and aphotic stromatolites and evoked a non-phototrophic behavior in Jurassic examples from Germany. Myrow and Coniglio [161], Böhm and Brachert [142], and Cavalazzi et al. [128] have interpreted a cryptobiontic lifestyle for the organisms producing Frutexites. Bacterial and fungal communities have been recorded related to Fe-Mn crusts in Pleistocene and modern examples from submarine caves in the Mediterranean [134,162,163], and from reef caves at Lizard Island in Great Barrier Reef [164]. These observations confirm the growth of such Fe-Mn coatings in reduced light conditions. Heim et al. [165] have reported living Frutexites-like biofilms at $160 \mathrm{~m}$ depth in Sweden. These authors have found abundant bacteria involved in the $\mathrm{N}$ and Fe cycling, as well as Archaea and biomarkers from algal and fungal origins, but the interactions of this complex community and the role in the growth of dendritic microstructures remain unclear.

The sessile foraminifera, as secondary components in the fossil assemblage, are compatible with the cryptobiontic behavior interpreted by the serpulids and Frutexites. The different species of encrusting foraminifera associated with the Frutexites, such as Bullopora tuberculata, Tolypammina vagans, and Thurammina hausleri, were reported previously as a common inhabitant of cryptic microhabitats $[166,167]$. The colonization of Frutexites by sessile foraminifera rejects the option of a diagenetic origin of Frutexites.

\subsection{Hydrothermal Mn Microbial Crusts}

The mineralogical and geochemical composition of the studied Mn crust from the Jbel Moussa (Rifian Calcareous Chain) are consistent with a hydrothermal origin [47]. In particular, the values (in ppm) of $\mathrm{Cu}$ (201), $\mathrm{Ni}$ (131), Zn (95), $\mathrm{Co}$ (87), and Pb (2) for the Mn crust are within the hydrothermal range according to the values of these elements given by Glasby [43] for the hydrothermal Mn crusts in modern oceans. Moreover, the $\mathrm{Mn} / \mathrm{Fe}$ ratio exceeding 40 (some samples $\mathrm{Mn} / \mathrm{Fe}=87$ ) is also characteristic of hydrothermal manganese precipitates [41,168,169]. According to Glasby [43], the hydrothermal Mn crusts in modern oceans can have Mn/Fe ratios from 10 to 4670. In the studied crust the low $\sum$ REE (11 ppm), the negative Ce, and positive Eu anomalies respect to PAAS-normalized patterns are data characteristics of hydrothermal Mn crusts [42,169-172]. In particular, high Eu 
anomalies in the deposits typically evidence a process of leaching of $\mathrm{Eu}^{2+}$ from the host rocks at temperatures above $250^{\circ} \mathrm{C}$. In addition, the enrichment in light REE relative to heavy REE, as it has been described in this case, is also characteristic of hydrothermal origin [171]. With respect to the mineralogy, the identified minerals (Ca-birnessite, cryptomelane, and coronadite) have already been described in hydrothermal vent deposits [173-175]. Specifically, birnessite is a biological-induced Mn mineral [40] that is poorly crystalline and a common component of the fossil microbial filaments that have been interpreted in relation to hydrothermal metal-enriched solutions $[176,177]$ and occasionally related to cryptomelane [178]. Coronadite has also been described in deposits related to hydrothermal vents and vein deposits $[174,175,179]$.

The record of BMC is compatible with the hydrothermal origin of Mn crusts. Modern microbialites occur abundantly in the vicinity of submarine hydrothermal vents, which are the source of nutrients for microbes that precipitate Mn oxides [49,50,152,180-183]. The precipitation of Mn minerals is interpreted as induced by the chemo-organotrophic behavior of BMC, since Mn oxides may form as a result of the direct metabolic activity of microbes $[40,143,180]$. Mn(II)-oxidizing bacteria and fungi are widespread and phylogenetically diverse [32]. Many authors have interpreted different types of eubacteria, inducing Fe and Mn mineralization [40]. Nevertheless, here we interpret the main filamentous structures observed in SEM images as fungal hyphae, also described in hydrothermal contexts [182]. The record of ascomycetes is compatible with the recognition of these fungi in modern deep-sea hydrothermal ecosystems [184]. Less abundant components, such as the masses of bacillus-shaped forms, are very potentially related to eubacteria, and their association with the Mn oxidation cannot be ruled out in view of their importance in the precipitation of Mn crusts in hydrothermal environments [49,185]. Fungi most likely feed on bacteria and their by-products.

In modern environments, efficient precipitation of $\mathrm{Mn}$ from seawater depends basically on the activity of Mn-oxidizing microbes $[40,147,148,181,186]$. Oxidation of soluble $\mathrm{Mn}^{2+}$ to insoluble $\mathrm{Mn}^{4+}$ oxides results in an energy gain that some microbes can use. Some types of bacteria (like some Bacillus species) can increase the rates of precipitation of Mn-oxides up to 4 to 5 orders of magnitude with respect to abiotic precipitation [143,146,148]. Ehrlich [144] and Krumbein [27] indicated the influence of microbes in the origin of deep-sea manganese nodules. An essential source of $\mathrm{Mn}$ in marine settings is the hydrothermal activity related with global tectonic processes $[44,187]$. In hydrothermal vents this has been described a high microbial activity that enhances the scavenging of $\mathrm{Mn}$ and facilitates its precipitation [49]. The process could be related to increasing $\mathrm{pH}$ and Eh gradient created in the microenvironment around microbial clumps; oxic and alkaline conditions would have favored the precipitation of Mn $[143,188]$. In the studied crusts, the existence of mucilaginous biofilms around the microbes and their role as a Mn chelating compound secreted by microorganisms in the precipitation of authigenic minerals can be reasonably inferred by the occurrence of microbial microstructures. Tebo et al. [181] proposed oxidization of $\mathrm{Mn}^{2+}$ directly; fungi and bacteria use multicopper oxidase enzymes in one-electron step transfer reaction that obtain $\mathrm{Mn}^{3+}$. The $\mathrm{Mn}^{3+}$ would compete with $\mathrm{Fe}^{3+}$ for siderophore organic molecules (ligands) at the cell surface. The $\mathrm{Mn}^{3+}$ could act as an oxidant on these acids and precipitate $\mathrm{Mn}^{4+}$ on the cell surface [32,181]. Authigenesis process through the Mn previously enriched as amorphous precursor phases drive to a later precipitation as Mn oxides. Zubkov et al. [32] indicate that microbes can also indirectly oxidize $\mathrm{Mn}^{2+}$ by changing redox (Eh) and $\mathrm{pH}$ conditions around the cells.

\subsection{Hydrothermal Glauconitic Microbial Crusts}

The genesis of the green laminated crusts is probably related to hydrothermal processes rather than sedimentary ones, assuming the type of deposits related to the infilling of voids and veins among pillow-lavas, green crusts composed mainly by glauconite and celadonite, and secondarily by saponitic smectites, embedded within crystal masses of calcite and quartz. In particular, the morphology and texture of the studied glauconitic micas, forming laminated crusts and columns, is evidently different 
from the traditional classification of glaucony facies of Millot [189] and other works [190], mainly focused on sedimentary environments.

Maturation from nascent glauconite (glauconitic smectite) to highly evolved glauconite is associated with a diminution in $\mathrm{Al}, \mathrm{Si}, \mathrm{Mg}, \mathrm{Ca}$, and $\mathrm{Na}$ content and an increase in $\mathrm{Fe}$ and $\mathrm{K}$, generating a decreasingly expandable smectitic component [190-193]. In fact, the most mature glauconitic micas compositionally range celadonite composition $[111,137,194]$. Celadonite is a typical product of hydrothermal alteration processes of marine basalts in the field veinlets $[137,195-200]$ and it is likely that some studies reporting glauconite from hydrothermal contexts are in fact reporting celadonite.

The main phase of hydrothermal alteration of basalts had to occur under oxidizing conditions with a high sea-water/rock ratio, in an open-circulation regime, favoring the precipitation of common Fe-rich dioctahedral micas (glauconite and celadonite). When fluids circulate quickly, the environment is sufficiently oxidized for celadonite crystal growth. According to D'Antonio and Kristensen [201], a high LOI confirms a high sea-water/rock ratio, and that is the case of the samples of the Median Subbetic with a LOI ranging 18.9-23.8 wt. \%. In addition, the volcanic outcrops of the Median Subbetic are composed of K-rich pillow-lavas [69] being potential sources of K. Consequently, K and Fe could be supplied to the oxidation zone and fixed in the precipitation of glauconite and celadonite.

The glauconite precipitation in hydrothermal contexts occurs at temperatures ranging 30-60 ${ }^{\circ} \mathrm{C}$ [201,202]. In addition, Clauer et al. [203] interpreted a crystallization temperature of $32-63^{\circ} \mathrm{C}$ from $\delta^{18} \mathrm{O}$ values in the Galapagos Spreading Center. In turn, Stackes and O'Neil [204] and Odin et al. [198] interpreted temperatures $<50^{\circ} \mathrm{C}$ to precipitate celadonite from $\delta^{18} \mathrm{O}$ values. However, Odin et al. [198] and Desprairies et al. [205] sustain that celadonite occasionally forms at temperatures between 50 and $90^{\circ} \mathrm{C}$.

Andrews [191], Desprairies et al. [205], and Delmont [196] emphasized the association of celadonite with ferriferous saponite from veins recorded in marine volcanic rocks. In the studied examples from the Median Subbetic, a last phase of alteration is characterized by the formation of saponite, which occurred under confined conditions resulting from the deposition of marine sediments on the volcanic rocks [111]. When iron-bearing fluids circulate more slowly or are trapped, then the environment is dominated by the reducing property of the pillow-basalt. According to D'Antonio and Kristensen [201] and Reolid and Abad [111], glauconite characterizes hydrothermal alteration under oxidizing conditions, whereas saponite and calcite characterize alteration under reducing conditions. At any rate, there are substantial similarities among the products of low temperature hydrothermal alteration in the Subbetic pillow-lavas as compared with those from ocean-ridge basalts and oceanic crusts $[201,202,206]$, with the presence of early Fe-rich dioctahedral micas followed by a later formation of carbonates and saponitic smectites.

The record of filaments indicates the active role of BMC in the development of the glauconitic laminated crusts. Moreover, the existence of voids occupying the center of the glauconitic filaments points to the initial presence of organic matter related to microbes. BMC are ubiquitously registered on pillow-lavas in recent ocean crust [183,207,208]. According to Bach and Edwards [209] and Santelli et al. [208], basalt alteration reactions are capable of supplying enough energy for chemo-organotrophic growth of microbes. In the context of this research, the record of BMC is congruent with the interpreted hydrothermal origin of the glauconitic laminated crusts. Modern microbialites happen profusely near to submarine hydrothermal vents, which are the source of nutrients for microbes. Microbial communities that mediate the mineral precipitation, including iron compounds, have been described in hydrothermal chimneys, hydrothermal vents, and deep-sea volcanoes $[49,50,149,182,210,211]$. Moreover, the role of BMC in the origin of glauconitic micas has been pointed out previously in sedimentary environments [193,212-215] and hydrothermal environments [199,216]. However, the examples described in previous works usually concern peloidal glauconite, not laminated crusts. The laminated texture of the glauconitic crusts is compatible with the participation of microbial communities. The relatively high temperature of the hydrothermal environment and the cryptic conditions of these inter-pillow narrow spaces confirm these microbes had to be extremophile ones. Precipitation of iron could be related to increasing $\mathrm{pH}$ and Eh gradients in the microenvironment 
around microbial clumps; oxidizing and alkaline conditions would have favored the precipitation of $\mathrm{Fe}^{3+}$, whereas $\mathrm{CO}_{2}$ is reduced to form carbon organic compounds (carbohydrates). Microbial activity may stimulate glauconite formation working as a catalyzer, as well as the EPS serving as a specific trap for Fe and K. In the studied green laminated crusts, the existence of mucilaginous biofilms around the filaments and their role as a chelating compound in the EPS secreted by microorganisms in the precipitation of glauconite may be interpreted by the record of voids surrounded by glauconite reproducing the branching filamentous microstructures. Authigenesis occurred through the glauconitic precursor precipitated on the EPS. The mineralization of the microbial biofilms could also have happened simply as a result of passive attraction of $\mathrm{Fe}^{2+}$ ions from hydrothermal fluids to the negatively charged microbial EPS [217]. At modern hydrothermal vents, the passive mineralization is supposed to constitute the most important process of microbial encrustation with Fe [218]. Independently of the source of $\mathrm{Fe}^{2+}$, pillow-lava alteration or hydrothermal fluids, a rapid oxidation to $\mathrm{Fe}^{3+}$ on microbial surfaces, is possible.

The most advanced stage in the glauconitization process, the celadonite, resulted from (1) a later abiotic precipitation on filament surface with the inner glauconite being the nucleation site for subsequent growth of more complex authigenic celadonite, or (2) from successive reactions of recrystallisation trapping increasingly amounts of $\mathrm{K}$. The distribution of glauconite and celadonite, representing a Fe decreasing trend to the outer part of the filaments, agrees with Fe chemo-organotrophic processes for the precipitation of glauconite in the EPS. Eickmann et al. [219] described microendolithic microbes from Devonian basalts corresponding to branching filaments composed by an inner part of chamosite/glauconite surrounded by illite-glauconite. An important difference of these filaments, with respect to the examples of the pillow-lavas from the Median Subbetic, is the epilithic behavior of the microbes forming the green laminated crusts.

\section{Conclusions}

The Middle-Late Jurassic transition in the External Subbetic (Betic Cordillera) and the Rifian Calcareous Chain was characterized by the fragmentation of the carbonate epicontinental platforms that produced the configuration of tectonic blocks, with troughs and swells, propitiating submarine volcanic activity. In this context, different locations were favorable for developing non-carbonate microbialites: hardgrounds on epioceanic swells, submarine caves, hydrothermal vents, and voids and veins among pillow-lava bodies.

Numerous stratigraphic breaks have been recorded as hardgrounds with surficial iron crusts and macro-oncoids. These are hydrogenetic crusts related to the chemo-organotrophic behavior of BMC. Microbial biocoenoses served as a specific trap for Fe and Mn enrichment. In particular, the surficial iron crusts and macro-oncoids developed in pelagic swells of the External Subbetic due to microbially mediated authigenesis were favored by the low sedimentation rate and the presence of bottom currents that remove fine sediment and oxygenate the sea bottom.

The cryptic Fe-Mn crusts (or endostromatolites) recorded in the External Subbetic are hydrogenetic growths developed in the walls of submarine cavities and fractures. They are constituted almost exclusively by Frutexites, a chemosynthetic and cryptobiontic microorganism, in the case of thin neptunian-dykes, or by serpulid-Frutexites assemblages growing downward from the top walls of large neptunian-sills. This assemblage reflects the colonization of an unfavorable environment (aphotic and probably with low oxygenation) as a response to photophobic behavior.

The hydrothermal Mn crusts recorded in the Rifian Calcareous Chain are constituted by bacillus-shaped bacteria and different types of filaments. The mineralogy and geochemistry point to a submarine hydrothermal origin. The precipitation of manganese minerals would be induced by the chemo-organotrophic behavior of BMC that oxidized soluble $\mathrm{Mn}^{2+}$ to $\mathrm{Mn}^{4+}$. The best-preserved microbial structures are filaments interpreted as fungal hyphae, probably ascomycetes.

The glauconite laminated crusts were developed in cryptic spaces among the pillow-lava bodies in the Median Subbetic. These crusts are constituted by branched cylindrical filaments composed 
by glauconite and celadonite. These crusts were built by chemo-organotrophic microbes growing from pillow-lava walls under oxic conditions at temperatures between 30 and $90{ }^{\circ} \mathrm{C}$, favored by hydrothermal fluids mixed with seawater. Two possibilities are considered: (1) EPS worked as siderophore ligands that scavenge $\mathrm{Fe}^{3+}$ from seawater and deliver it to the cell surface, or (2) passive attraction of $\mathrm{Fe}^{2+}$ from hydrothermal fluids to the negatively charged microbial EPS. Authigenesis happened through the glauconite precursor precipitated on the EPS.

In all these cases, the life of the microbial cells ended when mineralization of EPS and cell walls by Fe-Mn oxides and oxyhidroxides or by glauconite-celadonite, produced the entombment of the cells in a shell of insoluble minerals. A new generation of cells is overlaid on the previous one, generating a laminar structure.

Author Contributions: M.R. conducted field observations and the sampling, performed observations of the fossil microbial structures in petrographic microscope and SEM (mineralogical, textural, and geochemical analyses), and obtained the elemental mappings by XR_microfluorescence; I.A. interpreted the X-ray diffractograms, obtained the structural formulae of minerals from SEM and EPMA data, handled the whole-rock analyses of the crusts obtained by XRF and ICP-MS, and analyzed the microbialites in the TEM. The two authors discussed the analytical results and prepared the manuscript and figures.

Funding: This research was funded by the University of Jaén, with the project UJA_07_16_23 and Research Groups RNM-200 and RNM-325 of the Junta de Andalucía.

Acknowledgments: We would like to thank Antonio Piedra (Technician of the Geologic Laboratory of Universidad de Jaén) for preparing the thin sections and polished slabs. Technical and human support provided by CICT of Universidad de Jaén (UJA, MINECO, Junta de Andalucía, FEDER) is gratefully acknowledged. We would like to thank the three anonymous reviewers for the careful supervision of the manuscript.

Conflicts of Interest: The authors declare no conflict of interest.

\section{References}

1. Burne, R.V.; Moore, L.S. Microbialites: Organosedimentary deposits of benthic microbial communities. Palaios 1987, 2, 241-254. [CrossRef]

2. Riding, R. Calcified Cyanobacteria. In Calcareous Algae and Stromatolites; Riding, R., Ed.; Springer: Berlin, Germany, 1991; pp. 21-51.

3. Riding, R. Structure and composition of organic reefs and carbonate mud mounds: Concepts and categories. Earth-Sci. Rev. 2002, 58, 163-231. [CrossRef]

4. Riding, R. Microbial carbonate abundance compared with fluctuations in metazoans diversity over geological time. Sed. Geol. 2006, 185, 229-238. [CrossRef]

5. Mata, S.A.; Bottjer, D.J. Microbes and mass extinctions: Paleoenvironmental distribution of microbialites during times of biotic crisis. Geobiology 2012, 10, 3-24. [CrossRef] [PubMed]

6. Lazar, I.; Gradinaru, M.; Petrescu, L. Ferruginous microstromatolites related to Middle Jurassic condensed sequences and hardgrounds (Bucegi Mountains, Southern Carpathians, Romania). Facies 2013, 59, 359-390. [CrossRef]

7. Salama, W.; El Aref, M.M.; Gaupp, R. Mineral evolution and processes of ferruginous microbialite accretion-An example from the Middle Eocene stromatolitic and ooidal ironstones of the Bahariya depression, Western Desert, Egypt. Geobiology 2013, 11, 15-28. [CrossRef] [PubMed]

8. Lozano, R.P.; Rossi, C. Exceptional preservation of Mn-oxidizing microbes in cave stromatolites (El Soplano, Spain). Sed. Geol. 2012, 255, 42-55. [CrossRef]

9. Wang, X.; Gan, L.; Wiens, M.; Schlossmacher, U.; Schroeder, H.C.; Muller, W.E.G. Distribution of microfossils within polymetallic nodules: Biogenic clusters within manganese layers. Mar. Biotech. 2012, 14, 96-105. [CrossRef]

10. Wu, Y.H.; Liao, L.; Wang, C.S.; Ma, W.L.; Meng, F.X.; Wu, M.; Xu, X.W. A comparison of microbial communitites in deep-sea polymetallic nodules and the surrounding sediments in the Pacific Ocean. Deep-Sea Res. Part I-Oceanogr. Res. Pap. 2013, 79, 40-49. [CrossRef]

11. Martín-Algarra, A.; Sánchez-Navas, A. Phosphate stromatolites from condensed cephalopod limestones, Upper Jurassic, Southern Spain. Sedimentology 1995, 42, 893-919. [CrossRef] 
12. Soudry, D. Microbial phosphate sediment. In Microbial Sediments; Riding, R., Awramik, S.M., Eds.; Springer: Berlin/Heidelberg, Germany, 2000; pp. 127-136.

13. Sallstedt, T.; Bengtson, S.; Broman, C.; Crill, P.M.; Canfield, D.E. Evidence of oxygenic phototrophy in ancient phosphatic stromatolites from the Paleoproterozoic Vindhyan and Aravalli Supergroups, India. Geobiology 2018, 16, 139-159. [CrossRef] [PubMed]

14. Rouchy, J.M.; Monty, C. Gypsum microbial sediments: Neogene and Modern examples. In Microbial Sediments; Riding, R., Awramik, S.M., Eds.; Springer: Berlin/Heidelberg, Germany, 2000; pp. 209-216.

15. Taher, A.G. Formation and calcification of modern gypsum-dominated stromatolites, EMISAL, Fayium, Egypt. Facies 2014, 60, 721-735. [CrossRef]

16. Stevens, E.W.N.; Bailey, J.V.; Flood, B.E.; Jones, D.S.; Gilhooly, W.P.; Joye, S.B.; Teske, A.; Mason, O.U. Barite encrustation of benthic sulfur-oxidizing bacteria at a marine cold seep. Geobiology 2015, 13, 588-603. [CrossRef] [PubMed]

17. Strohmenger, C.J.; Jameson, J. Gypsum stromatolites from Sawda nathil: Relicts from a southern coastline of Qatar. Carbonates Evaporites 2018, 33, 169-186. [CrossRef]

18. Wacey, D.; Urosevic, L.; Saunders, M.; George, A.D. Mineralisation of filamentous cyanobacteria in Lake Thetis stromatolites, Western Australia. Geobiology 2018, 16, 203-215. [CrossRef] [PubMed]

19. Gerdes, G.; Krumbein, W.E.; Nofke, N. Evaporite microbial sediments. In Microbial Sediments; Riding, R., Awramik, S.M., Eds.; Springer: Berlin/Heidelberg, Germany, 2000; pp. 196-208.

20. Renaut, R.W.; Jones, B. Microbial precipitates around continental hot springs and geysers. In Microbial Sediments; Riding, R., Awramik, S.M., Eds.; Springer: Berlin/Heidelberg, Germany, 2000; pp. 186-195.

21. Miller, S.L.; Bada, J.L. Submarine hot springs and the origin of life. Nature 1988, 334, 609-611. [CrossRef] [PubMed]

22. Rasmussen, B. Filamentous microfossils in a 3,235-million-year-old volcanogenic massive sulphide deposit. Nature 2000, 405, 676-679. [CrossRef] [PubMed]

23. Martin, W.; Baross, J.; Kelley, D.; Russell, M.J. Hydrothermal vents and the origin of life. Nature Rev. Microbiol. 2008, 6, 805-814. [CrossRef] [PubMed]

24. Boston, P.J.; Ivanov, M.V.; McKay, C.P. On the possibility of chemosynthetic ecosystems in subsurface habitat on Mars. Icarus 1992, 95, 300-308. [CrossRef]

25. Matsubara, T.; Fujishima, K.; Saltikov, C.W.; Nakamura, S.; Rothschild, L.J. Earth analogues for past and future life on Mars: Isolation of perchlorate resistant halophiles from Big Soda Lake. Int. J. Astrobiol. 2017, 16, 218-228. [CrossRef]

26. Brasier, A.; Wacey, D.; Rogerson, M.; Guagliardo, P.; Saunders, M.; Kellner, S.; Mercedes-Martín, R.; Prior, T.; Taylor, C.; Matthews, A.; et al. A microbial role in the construction of Mono Lake carbonate chimneys? Geobiology 2018, 16, 540-555. [CrossRef] [PubMed]

27. Krumbein, W.E. Microbial Geochemistry; Blackwell Scientific Publisher: London, UK, 1983.

28. Stolz, J.F. Structure of microbial mats and biofilms. In Microbial Sediments; Riding, R., Awramik, S.M., Eds.; Springer: Berlin/Heidelberg, Germany, 2000; pp. 1-8.

29. Tazaki, K. Microbial formation of a halloysite-like mineral. Clays Clay Miner. 2005, 53, 224-233. [CrossRef]

30. Lusty, P.A.; Murton, B.J. Deep-ocean mineral deposits: Metal resources and windows into Earth processes. Elements 2018, 14, 301-306. [CrossRef]

31. Perri, E.; Tucker, M.E.; Slowakiewicz, M.; Whitaker, F.; Bowen, L.; Perrotta, I.D. Carbonate and silicate biomineralization in a hypersaline microbial mat (Mesaieed sabkha, Qatar): Roles of bacteria, extracellular polymeric substances and viruses. Sedimentology 2018, 65, 1213-1245. [CrossRef]

32. Zubkov, M.V.; Plucinski, P.K.; Dartiguelongue, A.C.Y.; Lusty, P.A. Metal extraction from deep-ocean mineral deposits. Elements 2018, 14, 319-324. [CrossRef]

33. Schultze-Lam, S.; Harauz, G.; Beveridge, T.J. Participation of a cyanobacterial S-layer in fine-grain mineral formation. J. Bacteriol. 1992, 174, 7971-7981. [CrossRef] [PubMed]

34. Schultze-Lam, S.; Ferris, F.G.; Sherwood-Lollar, B.; Gerits, J.P. Ultrastructure and seasonal growth patterns of microbial mats in a temperature climate saline-alkaline lake: Goodenough Lake, British Columbia, Canada. Can. J. Microbiol. 1996, 42, 147-162. [CrossRef]

35. Schultze-Lam, S.; Fortin, D.; Beveridge, T.J. Mineralization of bacterial surfaces. Chem. Geol. 1996, 132, 171-181. [CrossRef] 
36. Cuadros, J. Clay minerals interaction with microorganisms: A review. Clay Miner. 2017, 52, $235-261$. [CrossRef]

37. Krumbein, W.E.; Jens, K. Biogenic rock varnishes of the Negev Desert (Israel), an ecological study of iron and manganese transformation by cyanobacteria and fungi. Oecologia 1981, 50, 25-38. [CrossRef]

38. Nealson, K.H. The microbial iron cycle. In Microbial Geochemistry; Krumbein, W.E., Ed.; Blackwell Scientific Publications: Oxford, UK, 1983; pp. 159-190.

39. Dahanayake, K.; Krumbein, W.E. Microbial structures in oolitic iron formations. Mineral. Depos. 1986, 21, 85-94. [CrossRef]

40. Frankel, R.B.; Bazylinski, D.A. Biologically induced mineralization by bacteria. Rev. Mineral. Geochem. 2003, 54, 95-114. [CrossRef]

41. Bolton, B.R.; Both, R.; Exon, N.F.; Hamilton, T.F.; Ostwald, J.; Smith, J.D. Geochemistry and mineralogy of seafloor hydrothermal and hydrogenetic Mn oxide deposits from the Manus Basin and Bismarck Archipelago region of the southwest Pacific Ocean. Mar. Geol. 1988, 85, 65-87. [CrossRef]

42. Hein, J.R.; Koschinsky, A.; Halbach, P.; Manheim, F.T.; Bau, M.; Kang, J.K.; Lubick, N. Iron and manganese oxide mineralization in the Pacific. Geol. Soc. Special Publ. 1997, 119, 123-138. [CrossRef]

43. Glasby, G.P. Manganese: Predominant role of nodules and crusts. In Marine Geochemistry; Schultz, H.D., Zabel, M., Eds.; Springer: Berlin/Heidelberg, Germany, 2000; pp. 350-372.

44. Rojkovič, I.; Aubrecht, R.; Mišik, M. Mineral and chemical composition of manganese hardgrounds in Jurassic limestones of the Western Carpathians. Geol. Carpathica 2003, 54, 317-328.

45. Jach, R.; Dudek, T. Origin of Toarcian manganese carbonate/silicate deposits from the Krížna unit, Tatra Mountains, Poland. Chem. Geol. 2005, 224, 136-152. [CrossRef]

46. Préat, A.; Mamet, B.; Di Stefano, P.; Martire, L.; Kolo, K. Microbially-induced Fe and Mn oxides in condensed pelagic sediments (Middle-Upper Jurassic, Western Sicily). Sed. Geol. 2011, 237, 179-188. [CrossRef]

47. Reolid, M.; El Kadiri, K.; Abad, I.; Olóriz, F.; Jiménez-Millán, J. Jurassic microbial communities in hydrothermal manganese crust from the Rifian Calcareous Chain, Northern Morocco. Sed. Geol. 2011, 233, 159-172. [CrossRef]

48. Rodríguez-Martínez, M.; Heim, C.; Simon, K.; Zilla, T.; Reitner, J. Tolypammina vagans Wendt 1969—Frutexites assemblage and ferromanganese crust: A coupled nutrient-metal interplay in the Carnian sedimentary condensed record of Hallstatt Facies (Austria). Lect. Notes Earth Sci. 2011, 31, 409-434.

49. Mandernack, K.W.; Tebo, B.M. Manganese scavenging and oxidation at hydrothermal vents and in vent plumes. Geochim. Cosmochim. Acta 1993, 57, 3907-3923. [CrossRef]

50. Templeton, A.S.; Knowles, E.J.; Eldridge, D.L.; Arey, B.W.; Dohnalkova, A.C.; Webb, S.M.; Bailey, B.E.; Tebo, B.M.; Staudigel, H. A seafloor microbial biome hosted within incipient ferromanganese crusts. Nat. Geosci. 2009, 2, 872-876. [CrossRef]

51. Reolid, M.; Nieto, L.M. Jurassic Fe-Mn macro-oncoids from pelagic swells of the External Subbetic (Spain): Evidences of microbial origin. Geol. Acta 2010, 8, 151-168.

52. Reolid, M.; Abad, I. The Middle-Upper Jurassic unconformity in the South Iberian palaeomargin (Western Tethys): A history of carbonate platform fragmentation, emersion and subsequent drowning. Jour. Iberian Geol. 2018. [CrossRef]

53. Tashiro, Y.; Tazaki, K. The primitive stage of microbial mats comprising iron hydroxides. Earth Sci. 1999, 53, 27-35.

54. Douglas, S.; Beveridge, T. Mineral formation by bacteria in natural microbial communities. FEMS Microbiol. Ecol. 1998, 26, 79-88. [CrossRef]

55. Fiore, S.; Dumontet, S.; Huertas, F.J.; Pasquale, V. Bacteria-induced crystallization of kaolinite. Appl. Clay Sci. 2011, 53, 566-571. [CrossRef]

56. Konhauser, K.O.; Fyfe, W.S.; Ferris, F.G.; Beveridge, T.J. Metal sorption and mineral precipitation by bacteria in tow Amazonian river systems: Rio Solimoes and Rio Negro, Brazil. Geology 1993, 21, 1103-1106. [CrossRef]

57. Konhauser, K.; Urrutia, M. Bacterial clay authigenesis: A common biogeochemical process. Chem. Geol. 1999, 161, 399-413. [CrossRef]

58. Kawano, M.; Tomita, K. Microbial biomineralization in weathered volcanic ash deposit and formation of biogenic minerals by experimental incubation. Am. Mineral. 2001, 86, 400-410. [CrossRef]

59. Ueshima, M.; Tazaki, K. Possible role of microbial polysaccharides in nontronite formation. Clays Clay Miner. 2001, 49, 292-299. [CrossRef] 
60. Sánchez-Navas, A.; Martín-Algarra, A.; Nieto, F. Bacterially-mediated authigenesus of clays in phosphate stromatolites. Sedimentology 1998, 45, 519-533. [CrossRef]

61. Guerrera, F.; Martín-Algarra, A.; Perrone, V. Late Oligocene-Miocene syn-/-late-orogenic successions in Western and Central Mediterranean Chains from the Betic Cordillera to the Southern Apennines. Terra Nova 1993, 5, 525-544. [CrossRef]

62. Vera, J.A. Evolution of the Iberian Continental Margin. Mémoires Muséum Natl. d'Histoire Nat. Paris 2001, 186, 109-143.

63. Durand-Delga, M.; Villiaumey, M. Sur la stratigraphie et la tectonique du Groupe du Jbel Musa (Rif septentrional, Maroc). Bull. Soc. Géol. France 1969, 5, 70-79.

64. Durand-Delga, M. La courbure de Gibraltar, extrémité occidentale des chaînes alpines, unit l'Europe et l'Afrique. Eclog. Geol. Helv. 1972, 65, 267-278.

65. El Kadiri, K.; Linares, A.; Olóriz, F. Les éléments du Groupe du Jbel Moussa (Chaîne Calcaire, Rif, Maroc): Évolutions stratigraphique el géodynamique au cours du Jurassique-Crétacé. Comunic. Serv. Geol. Portugal 1990, 76, 141-161.

66. El Hatimi, N. Rifting mésozoïque sur la Bordure Occidentale du Rif Interne (Maroc). Evolution Géodynamique d'un Secteur de la Marge Oust-Téthysienne. Exemples du Haouz et du Jbel Moussa. Ph.D. Thesis, Université Pau, Pau, France, 1991.

67. García-Hernández, M.; López-Garrido, A.C.; Martín-Algarra, A.; Molina, J.M.; Ruiz-Ortiz, P.A.; Vera, J.A. Las discontinuidades mayores del Jurásico de las Zonas Externas de las Cordilleras Béticas: Análisis e interpretación de los ciclos sedimentarios. Cuad. Geol. Ibérica 1989, 13, 35-52.

68. Comas, M.C.; Puga, E.; Bargossi, G.M.; Morten, L.; Rossi, P.L. Paleogeography, sedimentation and volcanism of the Central Subbetic Zone, Betic Cordilleras, Southeastern Spain. Neues Jahrbuch Geol. Paläontol. Monatsh. 1986, 7, 385-404.

69. Vera, J.A.; Molina, J.M.; Montero, P.; Bea, F. Jurassic guyots in the Southern Iberian Continental Margin: A model of isolated carbonate platforms on volcanic submarine edifices. Terra Nova 1997, 9, 163-166. [CrossRef]

70. Soussi, M.; Ben Ismail, M.H. Platform collapse and pelagic seamount facies: Jurassic development of vcentral Tunisia. Sed. Geol. 2000, 133, 93-113. [CrossRef]

71. Bouaziz, S.; Barrier, E.; Soussi, M.; Turki, M.M.; Zouari, H. Tectonic evolution of the northern African margin in Tunisia from paleostress data and sedimentary record. Tectonophysics 2002, 357, 227-253. [CrossRef]

72. Tanfous Amri, D.; Bédir, M.; Soussi, M.; Azaiez, H.; Zitouni, L.; Inoubli, M.H.; Boubaker, K.M. Halocinèse précoce associée au rifting jurassique dans l'Atlas central de Tunisie (region de Majoura-El Hfay). C. R. Géosci. 2005, 337, 703-711. [CrossRef]

73. Marok, A.; Reolid, M. Lower Jurassic sediments from the Rhar Roubane Mountains (Western Algeria): Stratigraphic precisions and synsedimentary block-faulting. J. Afr. Earth Sci. 2012, 76, 50-65. [CrossRef]

74. Soussi, M.; M'rabet, A. Las facies à oolithes ferrugineuses ('oolitic ironstones') du Jurassique moyen de l'Axe Nord-Sud (Tunisie centrale): Caractéristiques et significations. Notes Serv. Géol. Tunisie 1991, 57, 71-85.

75. El Kadiri, K. Jurassic ferruginous hardgrounds of the "Dorsale Calcaire" and the Jbel Moussa Group (Internal Rif, Morocco): Stratigraphical context and paleoceanographic consequences of mineralization processes. Geol. Romana 2002, 36, 33-69.

76. Aurell, M.; Fernández-López, S.; Meléndez, G. The Middle-Upper Jurassic oolitic ironstone level in the Iberian Range (Spain). Eustatic implications. Geobios 1994, 17, 549-561. [CrossRef]

77. Aurell, M.; Badenas, B.; Bello, J.; Delvene, G.; Meléndez, G.; Pérez-Urresti, I.; Ramajo, J. El Calloviense y el Jurasico Superior en la Cordillera Ibérica Nororiental y la zona de enlace con la Cordillera Costero Catalana, en los sectores de Sierra de Arcos, Calanda y Xerta-Paüls. Cuad. Geol. Ibérica 1999, 25, 73-110.

78. Ramajo, J.; Aurell, M. Análisis sedimentológico de las discontinuidades y depósitos del Calloviense superior-Oxfordiense medio en la Cordillera Ibérica Noroccidental. Cuad. Geol. Ibérica 1997, 22, $213-236$.

79. Ramajo, J.; Aurell, M.; Cepría, J. Análisis de facies de la Capa de oolitos ferruginosos de Arroyofrío en la Sierra de Arcos (Jurásico, Cordillera Ibérica septentrional). J. Iberian Geol. 2002, 28, 45-64.

80. Meléndez, G.; Ramajo, J.; Martínez-Cotanda, S. El desarrollo de la Capa de Arroyofrío (límite Calloviense-Oxfordiense) al Sur de Zaragoza, entre Ricla y Aguilón: Bioestratigrafía y facies. Geogaceta 2005, 38, 3-6. 
81. Scouflaire, Q.; Marchand, D.; Bonnot, A.; Courville, P.; Raffray, M.; Huault, V. Le contact Callovien-Oxfordien dans les environs de Chaignay: Nouvelles données stratigraphiques et paléontologiques. Bull. Sci. Bour. 1997, 49, 45-63.

82. Courville, P.; Collin, P.Y. La série du Callovien et de l'Oxfordien de Veuxhaulles (Châtillonnais, Côte d'Or): Problèmes de datation, de géométrie et de paléoenvironnements dans une série "condensée". Bull. Sci. Bourg. 1997, 49, 29-43.

83. Lorin, S.; Courville, P.; Collin, P.Y.; Thierry, J.; Tort, A. Modalités de réinstallation d'une plate-forme carbonatée après une crise sédimentaire: Exemple de la limite Oxfordien moyen-Oxfordien supérieur dans le Sud-Est du Bassin de Paris. Bull. Soc. Géol. Fr. 2004, 175, 289-302. [CrossRef]

84. Collin, P.Y.; Loreau, J.P.; Courville, P. Depositional environments and iron ooids formation in condensed sections (Callovian-Oxfordian, south-eastern Paris basin, France). Sedimentology 2005, 52, 969-985. [CrossRef]

85. Gygi, R.A. Oolitic iron formations: Marine or not marine? Eclog. Geol. Helv. 1981, 74, 233-254.

86. Huber, B.; Müller, B.; Luterbacher, H. Mikropaläontologische Untersuchungen an der Callovien/OxfordienGrenze im Schweizer Jura und auf der Schwäbischen Alb (vorläufige Mitteilung). Eclog. Geol. Helv. 1987, 80, 449-459.

87. Gygi, R.A.; Persoz, F. The epicontinental sea of Swabia (southern Germany) in the Late Jurassic: Factors controlling sedimentation. N. J. Geol. Paläont. Abh. 1987, 176, 49-65.

88. Sequeiros, L. Paleobiogeografía del Calloviense y el Oxfordiense en el Sector Central de la Zona Subbética. Ph.D. Thesis, Universidad de Granada, Granada, Spain, 1974.

89. Sequeiros, L. Caracterización cuali-cuantitativa del Calloviense de Cabra (Cordillera Bética, España). Bol. Real Soc. Española Hist. Nat. 1987, 83, 25-46.

90. Seyfried, H. Der Subbetische Jura von Murcia (Sudost-Spanien). Geol. J. 1978, 29, 3-204.

91. García-Hernández, M.; López-Garrido, A.C.; Rivas, P.; Sanz de Galdeano, C.; Vera, J.A. Mesozoic paleogeographic evolution of the External Zones of the Betic Cordillera. Geol. Minjbow 1980, 59, 155-168.

92. Sandoval, J. Bioestratigrafía y Paleontología (Stephanocerataceae y Perisphinctaceae) del Bajocense y Bathonense en las Cordilleras Béticas. Ph.D. Thesis, Universidad Granada, Granada, Spain, 1983.

93. Marques, B.; Olóriz, F.; Rodríguez-Tovar, F.J. Interactions between tectonics and eustasy during the Upper Jurassic and lowermost Cretaceous. Examples from the south of Iberia. Bull. Soc. Géol. Fr. 1991, 162, 1109-1124.

94. Martín-Algarra, A.; Vera, J.A. Mesozoic pelagic phosphate stromatolites from the Penibetic (Betic Cordillera Southern Spain). In Phanerozoic Stromatolites II; Bertrand-Sarfati, J., Monty, C., Eds.; Kluwer Academic Publishers: Dordrecht, The Netherlands, 1994; pp. 345-391.

95. O'Dogherty, L.; Sandoval, J.; Vera, J.A. Ammonite faunal turnover tracing sea level changes during the Jurassic (Betic Cordillera, southern Spain). Jour. Geol. Soc. Lond. 2000, 157, 723-736. [CrossRef]

96. Reolid, M.; Abad, I.; Martín-García, J.M. Palaeoenvironmental implications of ferruginous deposits related to a Middle-Upper Jurassic discontinuity (Prebetic Zone, Betic Cordillera, Southern Spain). Sed. Geol. 2008, 203, 1-16. [CrossRef]

97. Reolid, M.; Nieto, L.M.; Rey, J. Taphonomy of cephalopod assemblages from Middle Jurassic hardgrounds of pelagic swells (South-Iberian Palaeomargin, Western Tethys). Palaeogeogr. Palaeoclimatol. Palaeoecol. 2010, 292, 257-271. [CrossRef]

98. Vera, J.A.; Martín-Algarra, A.; Sánchez-Gómez, M.; Fornós, J.J.; Gelabert, B. Cordillera Bética y Baleares. In Geología de España; Vera, J.A., Ed.; SGE-IGME: Madrid, Spain, 2004; pp. 347-464.

99. Molina, J.M. Análisis de facies del Mesozoico en el Subbético Externo (Provincia de Córdoba y Sur de Jaén). Ph.D. Thesis, Universidad de Granada, Granada, Spain, 1987.

100. Rey, J. Análisis de la Cuenca Subbética durante el Jurásico y el Cretácico en la transversal Caravaca-Vélez Rubio. Ph.D. Thesis, Universidad de Granada, Granada, Spain, 1993.

101. Nieto, L.M. La Cuenca Subbética Mesozoica en el Sector Oriental de las Cordilleras Béticas. Ph.D. Thesis, Universidad de Jaén, Jaén, Spain, 1997.

102. Molina, J.M.; Ruiz-Ortiz, P.A.; Vera, J.A. Neptunian dykes and associated features in southern Spain: Mechanisms of formation and tectonic implications. Discussion. Sedimentology 1995, 42, 957-960. [CrossRef]

103. Molina, J.M.; Ruiz-Ortiz, P.A.; Vera, J.A. A review of polyphase karstification in extensional tectonic regimes: Jurassic and Cretaceous examples, Betic Cordillera, southern Spain. Sed. Geol. 1999, 129, 71-84. [CrossRef] 
104. Reolid, M.; Molina, J.M. Serpulid-Frutexites assemblage from shadow-cryptic environments in Jurassic marine caves (Betic Cordillera, South Spain). Palaios 2010, 25, 468-474. [CrossRef]

105. Puga, E.; van de Fliert, J.R.; Torres-Roldán, R.L.; Sanz de Galdeano, C. Attempts of the whole-rock K/Ar dating of Mesozoic volcanic and hypabissal igneous rocks from the central Subbetic (Southern Spain): A case of differential argon loss related to very low-grade metamorphism. Estud. Geol. 1988, 44, 47-59. [CrossRef]

106. Puga, E.; Portugal, M.; Díaz de Federico, A.; Bargossi, G.M.; Morten, L. The evolution of the magmatism in the external zones of the Betic Cordilleras during the Mesozoic. Geodinamica Acta 1989, 3, 253-266. [CrossRef]

107. Morata, D.A.; Puga, E.; Demant, A.; Aguirre, L. Evolución petrogenética del magmatismo básico mesozoico en las Zonas Externas de las Cordilleras Béticas (S. España). Geogaceta 1986, 20, 576-578.

108. Abad, I.; Jiménez-Millán, J.; Molina, J.M.; Nieto, F.; Vera, J.A. Anomalous reverse zoning of saponite and corrensite caused by contact metamorphism and hydrothermal alteration of marly rocks associated with subvolcanic bodies. Clays Clay Miner. 2003, 51, 543-554. [CrossRef]

109. Jiménez-Millán, J.; Abad, I.; Nieto, F. Contrasting alteration processes in hydrothermally altered dolerites from the Betic Cordillera, Spain. Clay Miner. 2008, 43, 267-280. [CrossRef]

110. El Kadiri, K. La Dorsale Calcaire (Rif Interne, Maroc): Stratigraphie, Sédimentologie Etévolution Géodynamique d'une Marge Alpine Durant le Mésozoïque. Mise en Evidence d'un Modèle. Ph.D. Thesis, Université Tétouan, Tétouan, Morocco, 1991.

111. Reolid, M.; Abad, I. Glauconitic laminated crusts from hydrothermal alteration of Jurassic pillow-lavas (Betic Cordillera, S Spain): A microbial influence case. J. Iberian Geol. 2014, 40, 389-408. [CrossRef]

112. Taylor, S.R.; McLennan, S.M. The Continental Crust: Its Composition and Evolution; Blackwell Scientific: Oxford, UK, 1985.

113. McDonough, W.F.; Sun, S.S. The composition of the Earth. Chem. Geol. 1995, 120, 223-253. [CrossRef]

114. Monty, C. Cavity and fissure dwelling stromatolites (endostromatolites) from Belgian Devonian mud mounds. Ann. Soc. Géol. Belgique 1984, 105, 343-344.

115. Burkhalter, R.M. Ooidal ironstones and ferruginous microbialites: Origin and relation to sequence stratigraphy (Aalenian and Bajocian, Swiss Jura mountains). Sedimentology 1995, 42, 57-74. [CrossRef]

116. Lozano, R.P.; Rossi, C.; La Iglesia, A.; Matesanz, E. Zaccagnaite-3R, a new Zn-Al hydrotalcite polytype from El Soplao cave (Cantabria, Spain). Am. Mineral. 2012, 97, 513-523. [CrossRef]

117. Rossi, C.; Villalain, J.J.; Lozano, R.P.; Hellstrom, J. Paleo-watertable definition using cave ferromanganese stromatolites and associated cave-wall notches (Sierra de Arnero, Spain). Geomorphology 2016, 261, 57-75. [CrossRef]

118. Nieto, L.M.; Reolid, M.; Molina, J.M.; Ruiz-Ortiz, P.A.; Jiménez-Millán, J.; Rey, J. Evolution of pelagic swells from hardground analysis (Bathonian-Oxfordian, Eastern External Subbetic, southern Spain). Facies 2012, 58, 389-414. [CrossRef]

119. Nieto, L.M.; Rodríguez-Tovar, F.J.; Molina, J.M.; Reolid, M.; Ruiz-Ortiz, P.A. Unconformity surfaces in pelagic carbonate environments: A case from the Middle Bathonian of the Betic Cordillera, SE Spain. Ann. Soc. Geol. Pol. 2014, 84, 281-295.

120. Jiménez-Millán, J.; Nieto, L.M. Geochemical and mineralogical evidence of tectonic and sedimentary factors controlling the origin of ferromanganese crusts associates to stratigraphic discontinuities (Betic Cordilleras, SE of Spain). Chem. Erde 2008, 68, 323-336. [CrossRef]

121. Han, X.; Jin, X.; Yang, S.; Fietzke, J.; Eisenhauer, A. Rhythmic growth of Pacific ferromanganese nodules and their Milankovitch climatic origin. Earth Planet. Sci. Lett. 2003, 211, 143-157. [CrossRef]

122. Fleet, A.J. Hydrotermal and hydrogenous ferromanganese deposits: Do they from a continuum? The rare evidence. In Hydrothernal Processes at Seafloor Spreading Centers; Plenum Press: New York, NY, USA, 1983; pp. 535-555.

123. Fromm, R.; Hachicha, T.; Smykatz-Kloss, W. Aridic crusts and vein mineralization in the playa Areg el Makrezene, South Tunisia. Chem. Erde Geochem. 2005, 65, 357-373. [CrossRef]

124. Reolid, M.; Gaillard, C.; Olóriz, F.; Rodríguez-Tovar, F.J. Microbial encrustation from the Middle Oxfordianearliest Kimmeridgian lithofacies in the Prebetic Zone (Betic Cordillera, southern Spain): Characterization, distribution and controlling factors. Facies 2005, 50, 529-543. [CrossRef]

125. Nose, M.; Schmid, D.U.; Leinfelder, R.R. Significance of microbialites, calcimicrobes, and calcareous algae in reefal framework formation from the Silurian of Gotland, Sweden. Sed. Geol. 2006, 192, 243-265. [CrossRef] 
126. Perri, E.; Tucker, M. Bacterial fossils and microbial dolomite in Triassic stromatolites. Geology 2007, 35, 207-210. [CrossRef]

127. Gerdes, G.; Klenke, T.; Nofke, N. Microbial signatures in peritidal siliciclastic sediments: A catalogue. Sedimentology 2000, 47, 279-308. [CrossRef]

128. Cavalazzi, B.; Barbieri, R.; Ori, G.G. Chemosynthetic microbialites in the Devonian carbonate mounds of Hamar Laghdad (Anti-Atlas, Morocco). Sed. Geol. 2007, 200, 73-88. [CrossRef]

129. Playford, P.E.; Cockbain, A.E.; Druce, E.C.; Wray, J.L. Devonian stromatolites from the Canning Basin, Western Australia. Dev. Sedimentol. 1976, 20, 543-563.

130. Playford, P.E.; McLaren, D.J.; Orth, C.; Gilmore, J.S.; Goodfellow, W.D. Iridium anomaly in the Upper Devonian of the Canning Basin, Western Australia. Science 1984, 226, 437-439. [CrossRef]

131. Nicoll, R.S.; Playford, P.E. Upper Devonian iridium anomalies, conodont zonation and the FrasnianFammenian boundary in the Canning Basin, Western Australia. Palaeogeogr. Palaeoclimatol. Palaeoecol. 1993, 104, 105-113. [CrossRef]

132. Walter, M.R.; Awramik, S.M. Frutexites from stromatolites of the Gunflint Iron Formation of Canada, and its biological affinities. Precambrian Res. 1979, 9, 23-33. [CrossRef]

133. Hofmann, H.J.; Grotzinger, J.P. Shelf-facies microbiotas from the Odjick and Rocknest foramtions (Epworth Group; 1.89 Ga), northwesttern Canada. Can. J. Earth Sci. 1985, 30, 1781-1792. [CrossRef]

134. Guido, A.; Rosso, A.; Sanfilippo, R.; Russo, F.; Mastandrea, A. Frutexites from microbial/metazoan bioscontructions of recent and Pleistocene marine caves (Sicily, Italy). Palaeogeogr. Palaeoclimatol. Palaeoecol. 2016, 453, 127-138. [CrossRef]

135. Alexopoulos, C.J.; Mims, C.W.; Blackwell, M. 1996. Introductory Mycology; John Wiley \& Sons Inc.: Toronto, ON, USA, 1996; p. 869.

136. Bornhold, B.D.; Giresse, P. Glauconitic sediments on the continental shelf off Vancouver Island, British Columbia, Canada. J. Sed. Petrol. 1985, 55, 653-664.

137. Tóth, E.; Weiszburg, T.G.; Jeffries, T.; Williams, C.T.; Bartha, A.; Bertalan, E.; Cora, I. Submicroscopic accessory minerals overprinting clay mineral REE patterns (celadonite-glauconite group examples). Chem. Geol. 2010, 269, 312-328. [CrossRef]

138. Martín-Algarra, A.; Sánchez-Navas, A. Bacterially mediated authigenesis in Mesozoic stromatolites from condensed pelagic sediments (Betic Cordillera, Southern Spain). SEPM Spec. Pub. 2000, 66, 499-525.

139. Fortin, D.; Langley, S. Formation and occurrence of biogenic iron-rich minerals. Earth-Sci. Rev. 2005, 72, 1-19. [CrossRef]

140. Southam, G. Bacterial surface-mediated mineral formation. In Environmental Microbe-Mineral Interactions; Lovley, D.R., Ed.; ASM Press: Washington, DC, USA, 2000; pp. 257-276.

141. Hanert, H.H. The genus Siderocapsa (and other iron- and manganese-oxidizing eubacteria). Prokaryotes 2006, 7, 1005-1015.

142. Böhm, F.; Brachert, T.C. Deep-water stromatolites and Frutexites Maslov from the Early and Middle Jurassic of S-Germany and Austria. Facies 1993, 28, 145-168. [CrossRef]

143. Chafetz, H.S.; Akdim, B.; Julia, R.; Reid, A. Mn- and Fe-rich black travertine shrubs: Bacterially (and nanobacterially) induced precipitates. J. Sed. Res. 1998, 68, 404-413. [CrossRef]

144. Ehrlich, H.L. The formation of ores in the sedimentary environment of the deep sea with microbial participation: The case for ferromanganese concretions. Soil Sci. 1975, 119, 36-41. [CrossRef]

145. Schaefer, M.O.; Gutzmer, J.; Beukes, N.J. Late Paleoproterozoic Mn-rich oncoids: Earliest evidence for microbially mediated Mn precipitation. Geology 2001, 29, 835-838. [CrossRef]

146. Hasting, D.; Emerson, S. Oxidation of manganese by spores of a marine bacillus: Kinetic and thermodynamic considerations. Geochim. Cosmochim. Acta 1986, 50, 1819-1824. [CrossRef]

147. Nealson, K.H.; Stahl, D.A. Microorganisms and biochemical cycles: What can we learn from layered microbial communities? Rev. Mineral. 1997, 35, 5-34.

148. Francis, C.A.; Tebo, B.M. Enzymatic manganese (II) oxidation by metabolically dormant spores of diverse Bacillus species. Appl. Environ. Microbiol. 2002, 68, 874-880. [CrossRef] [PubMed]

149. Ghiorse, W.C.; Ehrlich, H.L. Microbial biomineralization of iron and manganese. Catena 1992, 21, 75-99.

150. Lewin, R. How microorganisms transport iron. Science 1984, 225, 401-402. [CrossRef]

151. Veillette, J.; Juniper, S.K.; Gooday, A.J.; Sarrazin, J. Influence of surface texture and microhabitat heterogeneity in structuring nodule faunal communities. Deep-Sea Res. I 2007, 54, 1936-1943. [CrossRef] 
152. Gooday, A.J.; Haynes, J.R. Abyssal foraminifers, including two new genera, encrusting the interior of Bathysiphon rusticus tubes. Deep-Sea Res. 1983, 30, 591-614. [CrossRef]

153. Lipps, J.H. Biotic interactions in benthic foraminifera. In Biotic Interaction in Modern and Fossil Benthic Communities; Tevesz, M.J.S., McCall, P.L., Eds.; Plenum Press: New York, NY, USA, 1983; pp. 331-376.

154. Kobluk, D.R. Cryptic faunas in reefs: Ecology and geologic importance. Palaios 1988, 3, 379-390. [CrossRef]

155. Toscano, F.; Raspini, A. Epilithozoan fauna associated with ferromanganese crustgrounds on the continental slope segment between Capri and Li Galli Islands (Bay of Salerno, Northern Tyrrhenian Sea, Italy). Facies 2005, 50, 427-441. [CrossRef]

156. Schlögl, J.; Michalík, J.; Zágoršek, A.; Atrops, F. Early Tithonian serpulid-dominated cavity-dwelling fauna and the recruitment pattern of the serpulid larvae. J. Paleontol. 2008, 82, 382-392. [CrossRef]

157. Wallace, M.W.; Keays, R.R.; Gostin, V.A. Stromatolitic iron oxides: Evidence that sea-level changes can cause sedimentary iridium anomalies. Geology 1991, 19, 551-554. [CrossRef]

158. Mamet, B.; Préat, A. Jurassic microfacies, Rosso Ammonitico limestone, Subbetic Cordillera, Spain. Rev. Española Micropal. 2006, 38, 219-228.

159. Jakubowicz, M.; Belka, Z.; Berkowski, B. Frutexites encrustations on rugose corals (Middle Devonian, southern Morocco): Complex growth of microbial microstromatolites. Facies 2014, 60, 631-650. [CrossRef]

160. Mišík, M.; Aubrecht, R. Some notes concerning mineralized hardgrounds (Jurassic and Cretaceous, Western Carpathians). Were all hardgrounds always hard from the beginning? Slovak Geol. Mag. 2004, 10, 183-202.

161. Myrow, P.M.; Coniglio, M. Origin and diagenesis of cryptobiontic Frutexites in the Chapel Island Formation (Vendian to Early Cambrian) of southeast Newfoundland, Canada. Palaios 1991, 6, 572-585. [CrossRef]

162. Allouc, J.; Harmelin, J.G. Les dépôts d'enduits manganoferrifères en environnement marin littoral. L'exemple de grottes sous-marines en Méditerrée nord-occidentale. Bull. Soc. Géol. Fr. 2001, 172, 765-778. [CrossRef]

163. Guido, A.; Jiménez, C.; Achilleos, K.; Rosso, A.; Sanfilippo, R.; Hadjioannou, L.; Petrou, A.; Russo, F.; Mastandrea, A. Cryptic serpulid-microbialite bioconstructions in the Kakoskali submarine cave (Cyprus, Eastern Mediterranean). Facies 2017, 63. [CrossRef]

164. Reitner, J.; Thiel, V.; Zankl, H.; Michaelis, W.; Wörheide, G.; Gautret, P. Organic and biogeochemical patterns in cryptic microbialites. In Microbial Sediments; Riding, R., Awramik, S.M., Eds.; Springer: Berlin/Heidelberg, Germany, 2000; pp. 149-160.

165. Heim, C.; Queric, N.V.; Lonescu, D.; Schafer, N.; Reitner, J. Frutexites-like structures formed by iron oxidizing biofilms in the continental subsurface (Aspo Hard Rock Laboratory, Sweden). PLoS ONE 2017, 12, E0177542. [CrossRef] [PubMed]

166. Olivier, N. Microbialites dans les Bioconstructions du Jurassique: Morphologies, rôles Edificateurs et Significations Paléoenvironnementales. Ph.D. Thesis, Université Claude-Bernard Lyon 1, Lyon, France, 2004.

167. Reolid, M.; Gaillard, C. Microtaphonomy of bioclasts and paleoecology of microencrusters from Upper Jurassic spongiolithic limestones (External Prebetic, Southern Spain). Facies 2007, 53, 97-112. [CrossRef]

168. Corliss, J.B.; Lyle, M.; Dymond, J.; Crane, K. The chemistry of hydrothermal mounds near Galapagos Rift. Earth Planet. Sci. Lett. 1978, 40, 12-24. [CrossRef]

169. Usui, A.; Bau, M.; Yamazaki, T. Manganese microchimneys buried in the Central Pacific pelagic sediments: Evidence of intraplate water circulation? Mar. Geol. 1997, 141, 269-285. [CrossRef]

170. Matsumoto, R.; Minai, Y.; Iijima, A. Manganese content, Cerium anomaly, and rate of sedimentation as clues to characterize and classify deep sea sediments. In Advances in Earth and Planetary Sciences, Formation of Oceanic Margin; Terra Science Publications: Tokyo, Japan, 1985; pp. 913-939.

171. Mills, R.A.; Eldefield, H. Rare earth element geochemistry of hydrothermal deposits from the active TAG mound, $26^{\circ} \mathrm{N}$ Mid-Atlantic Ridge. Geochim. Cosmochim. Acta 1995, 59, 3511-3524. [CrossRef]

172. Kuhn, T.; Bau, M.; Blum, N.; Halbach, P. Origin of negative Ce anomalies in mixed hydrothermalhydrogenetic Fe-Mn crusts from the central Indian Ridge. Earth Planet. Sci. Lett. 1998, 163, 207-220. [CrossRef]

173. Lonsdale, P.; Burns, V.M.; Fisk, M. Nodules of hydrothermal birnessite in the caldera of a young seamount. Jour. Geol. 1980, 88, 611-618. [CrossRef]

174. Glasby, G.P.; Papavassiliou, C.T.; Mitsis, J.; Valsani-Jones, E.; Liakopoulos, A.; Renner, R.M. The Vani manganese deposits, Milos Island, Greece: A fossil stratabound Mn-Ba-Pb-Zn-As-Sb-W-rich hydrothermal deposit. Dev. Volcanol. 2005, 7, 255-291. 
175. Canet, C.; Prol-Ledesma, R.M. Mineralizing processes at shallow submarine hydrothermal vents: Examples from México. GSA Spec. Pap. 2007, 422, 359-376.

176. Koschinsky, A.; Hein, J.R. Uptake of elements from seawater by ferromanganese crusts: Solid-phase association and seawater speciation. Mar. Geol. 2003, 198, 331-351. [CrossRef]

177. Canet, C.; Prol-Ledesma, R.M.; Bandy, W.L.; Schaaf, P.; Linares, C.; Camprubí, A.; Tauler, E.; MorteraGutiérrez, C. Mineralogical and geochemical constraints on the origin of ferromanganese crusts from the Rivera Plate (western margin of Mexico). Mar. Geol. 2008, 251, 47-59. [CrossRef]

178. Corona-Esquivel, R.; Ortega-Gutiérrez, F.; Reyes-Salas, M.; Lozano-Santacruz, R.; Miranda-Gasca, M.A. Mineralogical study of the La Hueca Cretaceous iron-manganese deposit, Michoacán, Southwestern Mexico. Rev. Mex. Cienc. Geol. 2000, 17, 143-153.

179. Camprubí, A.; Canet, C.; Rodríguez-Díaz, A.A.; Prol-Ledesma, R.M.; Blanco-Florido, D.; Villanueva, R.E.; López-Sánchez, A. Geology, ore deposits and hydrothermal venting in Bahía Concepción, Baja California Sur, Mexico. Island Arc. 2008, 17, 6-25. [CrossRef]

180. Ehrlich, H.L. Geomicrobiology of manganese. In Geomicrobiology; Marcel Dekker: New York, NY, USA, 1996; pp. 389-489.

181. Tebo, B.M.; Bargar, J.R.; Clement, B.G.; Dick, G.J.; Murray, K.J.; Parker, D.; Verity, R.; Webb, S.M. Biogenic manganese oxides: Properties and mechanisms of formation. Ann. Rev. Earth Planet. Sci. 2004, 32, 287-328. [CrossRef]

182. Connell, L.; Barret, A.; Templeton, A.; Staudigel, H. Fungal diversity associated with Active Deep Sea Volcano: Vailulu'u Seamount, Samoa. Geomicrobiol. J. 2009, 26, 597-605. [CrossRef]

183. Santelli, C.M. Life in the deep sea. Nature Geoscience 2009, 2, 825-826. [CrossRef]

184. Le Calvez, T.; Burgaud, G.; Mahé, S.; Barbier, G.; Vandenkoornhuyse, P. Fungal diversity in deep-sea hydrothermal ecosystem. App. Environ. Microbiol. 2009, 75, 6415-6421. [CrossRef] [PubMed]

185. Dick, G.J.; Clement, B.G.; Webb, S.M.; Fodrie, F.J.; Bargar, J.R.; Tebo, B.M. Enzymatic microbial $\mathrm{Mn}(\mathrm{II})$ oxidation and Mn biooxide production in the Guaymas Basin deep-sea hydrothermal plume. Geochim. Cosmochim. Acta 2009, 73, 6517-6530. [CrossRef]

186. Peck, S.B. Bacterial deposition of iron and manganese oxides in North American caves. Nat. Assoc. Speleol. Bull. 1986, 48, 26-30.

187. Corbin, J.C.; Person, A.; Iatzoura, A.; Ferré, B.; Renard, M. Manganese in pelagic carbonates: Indication of major tectonic events during the geodynamic evolution of a passive continental margin (the Jurassic European Margin of the Tethys-Ligurian Sea). Palaeogeogr. Palaeoclimatol. Palaeoecol. 2000, 156, 123-138. [CrossRef]

188. Rankama, K.; Sahama, T.G. Geochemistry; University of Chicago Press: Chicago, IL, USA, 1960; p. 912.

189. Millot, G. Géologie des Argiles; Masson: Paris, France, 1964; p. 499.

190. Odin, G.S.; Fullagar, P.D. Geological significance of the glaucony facies. Dev. Sedimentol. 1988, 45, $295-332$.

191. Odin, G.S.; Matter, A. De glauconiarum origine. Sedimentology 1981, 28, 611-641. [CrossRef]

192. Amorosi, A. Glaucony and sequence stratigraphy: A conceptual framework of distribution in siliciclastic sequences. J. Sed. Res. 1995, 65, 419-425.

193. Eder, V.; Martín-Algarra, A.; Sánchez-Navas, A.; Zanin, Y.N.; Zamirailova, A.G.; Lebedevs, Y.N. Depositional controls on glaucony texture and composition, Upper Jurassic, West Siberian Basin. Sedimentology 2007, 54, 1365-1387. [CrossRef]

194. Rieder, M.; Cavazzini, G.; D’Yakonov, Y.S.; Frank-Lamenetskii, V.A.; Gottardi, G.; Guggenheim, S.; Koval, P.V.; Müller, G.; Neiva, A.M.R.; Radoslovich, E.W.; et al. Nomenclature of the micas. Can. Mineral. 1998, 36, 905-912. [CrossRef]

195. Andrews, A.J. Saponite and celadonite in layer 2 basalts DSDP Leg 37. Contrib. Miner. Petrol. 1980, 73, 323-340. [CrossRef]

196. Delmont, P. Smectites et Produtis D’altération des Basaltes Tertiaires des iles Faeroe (Atlantique Nord Est). Genèse, Évolution et Contribution à la Sédimentation Océanique. Ph.D. Thesis, Université de Bordeaux I, Bordeaux, France, 1985.

197. Staudigel, M.; Gillis, K.; Duncan, R. K-Ar and Rb-Sr ages of celadonites from the Troodos ophiolite, Cyprus. Geology 1986, 14, 72-75. [CrossRef]

198. Odin, G.S.; Desprairies, A.; Fullagar, P.D.; Bellon, H.; Decarreau, A.; Frohlich, F.; Zelvelder, M. Nature and geological significance of celadonite. Dev. Sedimentol. 1988, 45, 337-398. 
199. Tazaki, K.; Fyfe, W. Microbial green marine clay from Izu-Bonin (west pacific) deep-sea sediments. Chem. Geol. 1992, 102, 105-118. [CrossRef]

200. Renac, C.; Kyser, K.; Bowden, P.; Moine, B.; Cottin, J.Y. Hydrothermal fluid interaction in basaltic lava units, Kerguelen Archipelago (SW Indian Ocean). Eur. J. Miner. 2010, 22, 215-234. [CrossRef]

201. D'Antonio, M.; Kristensen, M.B. Hydrothermal alteration of oceanic crust in the West Philippine Sea Basin (Ocean Drilling Program Leg 195, Site 1201): Inferences from a mineral chemistry investigation. Mineral. Petrol. 2005, 83, 87-112. [CrossRef]

202. Clayton, T.; Pearce, R.B. Alteration mineralogy of Cretaceous basalt from ODP Site 1001, Leg 165 (Caribbean Sea). Clay Miner. 2000, 35, 719-733. [CrossRef]

203. Clauer, N.; O'Neil, J.R.; Honnorez, J.; Buatier, $\mathrm{M} .{ }^{87} \mathrm{Sr} /{ }^{86} \mathrm{Sr}$ and ${ }^{18} \mathrm{O} /{ }^{16} \mathrm{O}$ ratios of clays from a hydrothermal area near the Galapagos rift as records of origin, crystallization temperature and fluid composition. Mar. Geol. 2011, 288, 32-42. [CrossRef]

204. Stackes, D.S.; O'Neil, J.R. Mineralogy and stable isotope geochemistry of hydrothermaly altered oceanic rocks. Earth Planet. Sci. Lett. 1982, 57, 285-304. [CrossRef]

205. Desprairies, A.; Bonnot, C.; Jehanno, C.; Vernhet, S.; Joron, J.L. Mineralogy and Geochemistry of Alteration Products in Leg 81 Basalts; Initial Report DSDP 81; United States Government Publishing Office: Washington, DC, USA, 1984; pp. 733-742.

206. Alt, J.C. Very low-grade hydrothermal metamorphism of basic igneous rocks. In Low-Grade Metamorphism; Frey, M., Robinson, D., Eds.; Blackwell: Oxford, UK, 1999; pp. 169-201.

207. Edwards, K.J.; Bach, W.; McCollom, T.M. Geomicrobiology in oceanography: Microbe-mineral interactions at and below the sea-floor. Trends Microbiol. 2005, 13, 449-456. [CrossRef] [PubMed]

208. Santelli, C.M.; Orcutt, B.N.; Banning, E.; Bach, W.; Moyer, C.L.; Sogin, M.L.; Staudigel, H.; Edwards, K.J. Abundance and diversity of microbial life in ocean crust. Nature 2008, 453, 653-656. [CrossRef] [PubMed]

209. Bach, W.; Edwards, K.J. Iron and sulphide oxidation within the basaltic ocean crust: Implications for chemolithoautotrophic microbial biomass production. Geochim. Cosmochim. Acta 2003, 67, 3871-3887. [CrossRef]

210. Juniper, S.K.; Fouquet, Y. Filaments iron-silica deposits from modern and ancient hydrothermal sites. Can. Mineral. 1988, 26, 859-869.

211. Vanko, D.A.; Milby, B.J.; Heinzquith, S.W. Massive sulphides with fluid-inclusion-bearing quartz from a young seamount on the East Pacific Rise. Can. Mineral. 1991, 29, 453-460.

212. Geptner, A.R.; Ivanovskaya, T.A. Glauconite from Lower Cretaceous marine terrigenous rocks of England: A concept of biochemogenic origin. Lithol. Miner. Resour. 2000, 35, 487-499. [CrossRef]

213. Zanin, Y.N.; Eder, V.G.; Zamirailova, A.G. Bacterial forms in glauconites from Upper Jurassic deposits of the West Siberian Plate. Russ. Geol. Geophys. 2004, 45, 774-777.

214. Zanin, Y.N.; Eder, V.G.; Zamirailova, A.G. Mn-carbonates, glauconites and phosphorites in the Upper Jurassic Georgiev Formation of the West Siberian marine basin. Geophys. Res. Abstracts 2006, 8, A-00271.

215. Baldermann, A.; Warr, L.N.; Grathoff, G.H.; Dietzel, M. The rate and mechanism of deep-sea glauconite formation at the Ivory Coast-Ghana Marginal Ridge. Clays Clay Miner. 2013, 61, 258-276. [CrossRef]

216. Geptner, A.R.; Ivanovskaya, T.A.; Pokrovskaya, E.V.; Kuralenko, N.P. Glauconite from Paleogene volcano-terrigenous rocks in Western Kamchatka. Lithol. Miner. Resour. 2008, 43, 228-249. [CrossRef]

217. Beveridge, T.J.; Makin, S.A.; Kadurugamuwa, J.L.; Li, Z.S. Interactions between biofilms and the environments. FEMS Microbiol. Rev. 1997, 20, 291-303. [CrossRef] [PubMed]

218. Konhauser, K.O. Diversity of bacterial iron mineralization. Earth-Sci. Rev. 1998, 43, 91-121. [CrossRef]

219. Eickmann, B.; Bach, W.; Kiel, S.; Reitner, J.; Peckmann, J. Evidence for cryptoendolithic life in Devonian pillow basalts of Variscan orogens, Germany. Palaeogeogr. Palaeoclimatol. Palaeoecol. 2009, 283, 120-125. [CrossRef]

(C) 2019 by the authors. Licensee MDPI, Basel, Switzerland. This article is an open access article distributed under the terms and conditions of the Creative Commons Attribution (CC BY) license (http:/ / creativecommons.org/licenses/by/4.0/). 